\title{
International Financial Liberalization and Industry Growth*
}

\author{
Jonas Vlachos* and Daniel Waldenström**
}

2002-11-14

SSE/EFI Working Paper Series in Economics and Finance No. 513

\begin{abstract}
The growth effects of international financial liberalization and integration are investigated using the methodology and data developed by Rajan and Zingales (1998). The main result is that industries highly dependent on external financing do not experience higher growth in value added in countries with liberalized financial markets. Liberalization does, however, increase the growth rates of both production and firm creation among externally dependent industries - given that the countries have reached a relatively high level of financial development. These results are consistent both with increased competition and increased outsourcing. Some preliminary evidence point towards the latter explanation.
\end{abstract}

JEL Classification: F3, G1, O4

Keywords: Financial Liberalization, Financial Integration, Economic Growth

\footnotetext{
* We are grateful for comments from Hali Edison, Tore Ellingsen, Mariassunta Giannetti, Magnus Henrekson, Stefan de Vylder and participants at the Nordic Conference in Development Economics in Bergen, May 2002. We thank Gian Maria Milesi-Ferretti, Philip Lane, Graciela Kaminsky, Dennis Quinn, Raghuram Rajan, Sergio Schumkler and Luigi Zingales for sharing their data. All remaining errors are our own. Financial support from the Swedish Institute for Banking Research (Vlachos) and the Wallander foundation (Waldenström) is gratefully acknowledged.

* The Research Institute of Industrial Economics, P.O. Box 5501, SE-114 85 Stockholm, Sweden. E-mail: jonas.vlachos@iui.se.

${ }^{* *}$ Department of Economics, Stockholm School of Economics, P.O. Box 6501, SE, 11383 Stockholm, Sweden. E-mail: daniel.waldenstrom@hhs.se.
} 


\section{Introduction}

An important subject in international economics concerns the growth effects of international financial liberalization and integration. Despite substantial research efforts, it is fair to say that a consensus remains to be reached (see, e.g., the surveys by Eichengreen, 2001, Arteta et al., 2001, and Edison et al., 2002a). Whereas previous work has mainly approached the problem by considering growth rates of country aggregates, this paper analyzes growth effects at the industry level, using the well-known and widely used methodology and data from Rajan and Zingales (1998). We extend their analysis on financial development and growth by testing if industries highly dependent on external financing experience a faster growth in countries with liberalized capital accounts, liberalized equity markets, and that are well-integrated with global capital markets. Specifically, we look for growth effects in value added, production, and the number of establishments. The main result is that growth in value added is unrelated to all the investigated dimensions of liberalization. Both growth in the number of establishments and production is, however, higher when capital markets are liberalized, but only if the countries have reached a relatively high level of financial development.

These results are consistent with two explanations, a competition effect and an outsourcing effect. If financial liberalization reduces the financing constraints faced by new firms, firm creation is stimulated. When new firms enter a market, this generally means that competition and production increase while markups, and eventually profits, decrease. Hence, while there may be more firms and higher production on a market, the margins for each firm shrink and industry value-added may therefore be unaffected or even decrease. Outsourcing, on the other hand, would mean breaking up value added chains. A pattern of constant value added, a larger number of firms, and a higher level of (measured) production is therefore consistent with outsourcing. Some preliminary and indirect evidence point towards the latter explanation. To our knowledge, these links between financial liberalization, outsourcing and competition have not previously been analyzed and hence our paper is a first attempt at drawing attention to these issues.

The literature on the real effects of financial liberalization and integration is both large and growing. Most previous studies have focused on the aggregate growth effects. In a widely cited study, Rodrik (1998) finds no effect of liberalized capital accounts, either on the per capita GDP growth rate or the investment to GDP ratio. Using a somewhat different indicator of capital account liberalization, as well as different econometric techniques, both Quinn (1997) 
and Edwards (2001) find positive growth effects. Edwards qualifies his finding by noting that a certain level of economic development must be reached before an open capital account has positive growth effects. This controversy between Rodrik and Edwards is discussed by Arteta et al. (2001), who argue that it is largely due to the use of different indicators of capital account liberalization. While Rodrik uses the IMF binary indicator, Edwards uses a multi-level index of Quinn (1997) which, according to Arteta et al., also seems to be the more comprehensive of the two. In a recent study, Edison et al. (2002b) use a wide variety of indicators of international financial liberalization and integration, similar to those used in our study, and fail to find any effects on aggregate economic growth.

Another branch of the literature focuses on the growth effects of liberalizing equity markets. Henry $(2000 a, b)$ applies an event study approach to his careful classification of economic reforms in 11 developing countries and finds a temporary increase in stock prices and investments following stock market liberalization. Bekaert and Harvey (2000) use a similar approach and find the cost of capital to be somewhat reduced after a stock market liberalization. Using firm level evidence, Chari and Henry (2001) document an increase in firms' capital stocks post liberalization, but cannot confirm this to be due to a lower cost of capital. Using a different methodology to classify liberalization events, Bekaert et al. $(2000,2001)$ find a temporary increase in per capita growth rates following equity market liberalization. In a paper combining firm level and macroeconomic data, Harrison et al. (2001) document that foreign direct investments reduce, and capital account restrictions increase firms' financing constraints. Although this last paper is close to ours in spirit, it uses a completely different methodology. While we assume the industry dependence on external funds to be equal across countries, Harrison et al. calculate a proxy for firm level financial constraints using Euler equations. Although their proxy gives a more precise estimate of a firm's financial position than our indicator of external dependence, it is also subject to more severe endogeneity problems. Hence, the two approaches should be seen as complements rather than substitutes.

This paper is organized as follows. Section 2 outlines the basic methodology used in the paper and Section 3 describes the data. In Section 4, the results regarding capital account liberalization are presented and Section 5 shows the results on actual financial integration. Section 6 concludes. 


\section{The Basic Methodology}

If the liberalization of international capital movements relaxes the financial constraints faced by industrial corporations, industries highly dependent on external financing should grow faster in countries with deregulated capital markets than in those where the opposite applies. Similarly, industries dependent on external financing should grow faster in countries more integrated with international capital markets. In an influential paper, Rajan and Zingales (1998) ask a related question when investigating if industries highly dependent on external financing grow faster in countries with well-developed domestic financial markets. In order to make the results in the present paper as comparable to this study as possible, we use both the methodology and the basic data employed by Rajan and Zingales. To investigate the growth effects, we study the growth rates of real value added, real production, and the number of establishments. The motivation behind the last variable is that new firms are often established using funds raised externally from the banking sector or the stock market. These capital suppliers are, in turn, dependent on a sufficiently large capital market from which they can attract their own funding. When the size of a country's capital market is restricted, for example by restrictions on cross-border capital flows, the number of new projects that are financed will also be limited. If the mechanism that liberalized capital accounts eventually increases the pool of capital available to entrepreneurs is correct, then one should, according to our approach, be able to trace this effect on the industries that are relatively dependent on external financing.

Empirically, this means that we will estimate the following relationship

(2.1) Growth $_{i j}=\beta_{1}\left(\right.$ External dependence $_{i} \times$ Liberalization $_{j}($ or $)$ Integration $\left._{j}\right)+$

$$
\begin{aligned}
& \beta_{2}\left(\text { External dependence }_{i} \times \text { Financial development }_{j}\right)+ \\
& \beta_{3} \text { Industry share in } 1980_{i j}+\Sigma \beta_{4, i} D_{i}+\Sigma \beta_{5, j} D_{j}+\varepsilon_{i j} .
\end{aligned}
$$

$i$ is the industry and $j$ the country subscript. Growth ${ }_{i j}$ is the average annual growth rate over the period 1980-1990 of real value added, the number of establishments or real output. In the analysis below, we examine these three measures separately. Industry share in $1980_{i j}$ is industry $i$ 's share of total value added in manufacturing in country $j$ in $1980, D_{i}$ is a set of industry dummies, and $D_{j}$ a set of country dummies. We include interaction variables between indica- 
tors of financial liberalization or integration and the proxies of external dependence created by Rajan and Zingales, which constitute the prime variable of interest. The liberalization and integration indicators belong to three classes: rule-based indicators on capital account liberalization; rule-based indicators of equity market liberalization; and actual capital market integration as measured by flows and stocks of foreign direct and portfolio investments. The time period of the study, 1980-90, is determined by the measure of external dependence being calculated using 1980's data. Although we would have liked to include data from the 1990s in our analysis, we are aware of the fact external dependence measure, on which the entire approach crucially hinges, seems quite variable over time and hence needs to be updated as often as possible without creating serious inconsistencies in the results. ${ }^{1}$

The specification (2.1) means that we are looking for a growth effect of financial liberalization and integration on top of the growth effect of financial development. This is important to keep in mind since a possible channel through which international financial integration can affect growth is by enhancing the performance of the domestic financial sector (see, e.g., Levine and Zervos, 1998, Klein and Olivei, 1999, and Levine, 2001). Throughout the analysis we also split the country sample according to the level of financial development, having one group of countries above and one group below the median level of financial development. The background is the recent findings (e.g., Laeven, 2000; Edwards, 2001) that the impact of financial liberalization on growth may depend on the level of financial development in a country. ${ }^{2}$ Basically, this is mainly due to the fact that developed economies are better able to make productive use of new capital inflows than are emerging market economies. There is, however, no broad consensus along these lines and few studies have actually examined this impact.

As is common in the growth regression framework, there may be potential concerns about the endogeneity of the regressors. It is possible that countries where externally dependent industries were expected to grow rapidly during the 1980s were more prone to liberalize capital movements at the beginning of the decade. Therefore, besides the ordinary least squares, we

\footnotetext{
${ }^{1}$ Rajan and Zingales (1998) compute external dependency measures for 1970 and 1980 and report a correlation between these of approximately 0.75 .

${ }^{2}$ Edwards (2001) actually uses income rather than financial development when dividing the sample of countries into high- and low levels. We argue, however, that financial development is a more relevant dimension, since what really counts is the ability to allocate the capital to producers in the economy and not whether the country in general is rich.
} 
will also run two-stage regressions in order to instrument for the liberalization indicators. The instruments are described in the following section.

\section{Data}

Except for data on capital account liberalization, equity market liberalization, international financial integration and industry level output, all other data is thoroughly described by Rajan and Zingales (1998). For this reason, the discussion of these variables and their sources will be kept brief here. The period under consideration is the 1980's, and the data covers a maximum of 42 countries (for the country coverage among different sub-samples, see Table A1).

\subsection{Financial dependence}

Rajan and Zingales' indicator of industry dependence on external financing is based on the assumptions that there are underlying technological reasons why industries differ in their use of external funds, and that these persist across countries. Furthermore, they note that when financial markets work relatively frictionless, the supply of external financing will be very elastic. Differences in the actual use of external financing in such an economy will hence mainly reflect differences in demand for this type of funding. Arguing that the U.S. financial markets are the most advanced in the world, Rajan and Zingales use data on the actual external financing pattern of U.S. firms to calculate their measure of external dependence. More precisely, their measure is defined as capital expenditures minus the cash flow from operations, divided by capital expenditures. To smooth fluctuations, they use data on the firm's external financing and capital expenditure over a 10-year period. The median value of this calculation is then used to indicate the external dependency for each respective industry. ${ }^{3}$

\subsection{Financial development}

Following much of the literature on the impact of the financial sector on growth, we use two different proxies for financial development. Our first indicator is the total capitalization measured as the sum of domestic credits and stock market capitalization over GDP. Data on domestic credit is from the IMF International Financial Statistics (IFS), and stock market capitalization from IFC's Emerging Stock Markets Factbook. In addition, we use the account-

\footnotetext{
${ }^{3}$ According to this indicator, drugs and medicines (ISIC 3522) constitute the most externally dependent industry, while the tobacco industry (ISIC 314) is the least so.
} 
ing standards of a country. ${ }^{4}$ This index is constructed by the Center for International Financial Analysis and Research, and rates the annual reports of firms across countries. Focusing on information disclosure, this index proxies for the potential to obtain financing, rather than the actual outcome.

\subsection{Liberalization data}

As we incorporate indicators of capital account liberalization, equity market liberalization, and actual flows and stocks of international capital flows, we employ data from a variety of sources described below, which all use somewhat different methodologies when calculating their indicators. Here, all rule-based indicators are normalized between zero and one, where zero implies full restriction and one full liberalization according to the respective index. In Table 1, summary statistics and the correlates between the different indices are shown. As can been seen, these correlates are generally quite high.

\section{[Table 1]}

\subsubsection{Capital account liberalization}

The most commonly used indicator of capital account liberalization is based on data from the IMF Exchange Arrangements and Exchange Restrictions. In its simplest form, this indicator is a dummy variable taking the value 1 if there are any restrictions on capital account transactions, and 0 otherwise. Although this is a very crude measure, it will be used for the year 1980 (IMF80) as a starting point for our analysis. If the interaction term between external dependence and IMF80 is positive, this shows that industries highly dependent on external financing experienced a faster subsequent growth in countries where the capital account was open in 1980. As an alternative, this indicator is averaged over the 1980's (IMF8090), which means that it measures the proportion of years during the 1980's when the capital account has been classified as open by the IMF. ${ }^{5}$ While the IMF-indicators tell us whether a restriction is in place, they have little to say about how severe these restrictions actually are. In an attempt to correct for this shortcoming, Quinn (1997) has constructed an index for several years and a wide cross-section of countries, based on how strict the imposed regulations actually are. ${ }^{6}$ Here, the Quinn-index from 1982 (QCAP82) and the average between the 1982 and 1988 val-

\footnotetext{
${ }^{4}$ The results using accounting standards are available in the appendix.

${ }^{5}$ Similar indicators have been used by, for example Alesina et al. (1994) in a study of the determinants of capital controls, and Rodrik (1998) in a study on how capital controls affect growth, inflation and investments.
} 
ues (QCAP8288) are used. The Quinn-indices overlap with the rest of the data for 39 countries.

Which of these indices to use is not evident as Rodrik (1998), using the IMF index, and Edwards (2001), using the Quinn indices, actually reach different conclusions. Arteta et al. (2001) try to evaluate this controversy by testing the quality and consistency of the two indices. They find that the Quinn indices seem more useful and coherent than those of the IMF, although the latter contain a larger sample of countries. All the same, we use both indicators because the underlying issue remains unsolved. As will be seen, our results are basically consistent across these indices.

\subsubsection{Equity market liberalization}

In order to measure equity market liberalization, we first follow the classification in Bekaert et al. (2001). This indicator takes the value of one if equity markets are officially liberalized for foreign investors at a certain date, and zero otherwise. BHL80 thus indicates the policies in place in 1980, while BHL8090 is the proportion of years between 1980 and 1990 that equity markets were officially liberalized. These indicators are available for our full set of countries. Our second indicator is from Kaminsky and Schmukler (2001), who have constructed a database that attempts to take into account both different aspects of the liberalization process and the severity of the restrictions in place. Here, we use their index of stock market liberalization (KSSTOCK80 and KSSTOCK8090) which relates to the acquisition of shares in the domestic market by foreigners, the repatriation of capital, and the repatriation of interest and dividends. Unfortunately, these indices only overlap with the rest of the data for 22 countries.

\subsubsection{Integration data}

Measuring capital market integration is a well-known difficulty and several candidate measures are proposed in the literature, all carrying specific pros and cons. In this study, we consider capital flows and stocks relative to the GDP of each country. The focus is mainly on the effects of capital flows but Lane and Milesi-Feretti (2001) argue that stocks of capital constitute a measure alleviating some of the problems often associated with flow data, such as sharp fluctuations across short periods. Recognizing this point, we include both estimates of capital stocks (with the variable name CAPSTOCK) and flows (CAPFLOW) to achieve as complete

\footnotetext{
${ }^{6}$ Using the Quinn index of capital account restrictions, Edwards (2001) finds that an open capital account spurs aggregate economics growth.
} 
a picture as possible. Specifically, we use stocks and flows of inward and outward direct investments and portfolio assets and liabilities as a share of GDP, calculated as annual averages over the period 1980-90 and using data from Lane and Milesi-Feretti (2001). As always when using data on cross-country investments, the measures should be treated with great caution since the choice of calculation methods may be important. ${ }^{7}$

\subsubsection{Instruments}

As reported above, we will run instrumental variables (IV) estimations parallel to the ordinary least squares regressions in order to check for the potential reversed causality. As instruments for IMF80, we use lagged index values of the IMF indicator from the year 1970 and the Quinn (1997) indicator of capital account liberalization (QCAP) from the years 1958 and 1973. Similarly, QCAP82 is instrumented with its lagged values from 1958 and 1973, BHL80 and KSSTOCK80 are both instrumented with the Quinn capital account indexes from 1958 and 1973 as well as the Quinn (1997) indicator of both capital and current account regulation from the years 1958 and 1973. CAPSTOCK and CAPFLOW are instrumented with the country area (in square kilometers), population size in $\$ 1980$, total trade in 1975 and government spending in 1975, respectively, as shares of GDP. These data are from the World Bank's World Development Indicators (World Bank).

\subsection{Industry data}

The industry data is from the UN's Industrial Statistics Yearbook and covers manufacturing firms at the three- or four-digit ISIC-level. From Rajan and Zingales's data set, we get data on growth in value added and the number of establishments, or firm creation. ${ }^{8}$ As a complementtary measure of economic growth, we introduce growth in real output published in the Industrial Statistics Yearbook (and the more recent International Yearbook of Industrial Statistics) as output in nominal producer prices. To deflate the output, we follow the procedures of Rajan and Zingales (1998) to make the data comparable. This means that the Producer Price Index (PPI) is the prime deflator and for countries where no such index is available, an effective deflator is computed by dividing the growth in nominal output for the entire manufacturing industry (ISIC 300) by the index of industrial production, taken from the IFS statistics. For Jamaica and Turkey neither an index of production nor a PPI are available and we have thus

\footnotetext{
${ }^{7}$ For example, it could be of importance whether the investments are counted at market or book value, at which time of the year this is done, and in which of the two countries the valuation is done.
} 
used the Consumer Price Index to deflate the nominal output growth. In the case of Brazil, none of these procedures could produce a satisfactory deflator, mainly due to the extreme inflation and a large number of devaluations in Brazil during the 1980s.

\section{Results}

The results are presented using total capitalization as the measure of financial development. In the Appendix, however, we present all the parallel regressions where accounting standards have instead been used. On the whole, the results are stronger when we use total capitalization, although the other measure does not contradict the presented findings. We do not report the results for the indicators representing multi-year averages (IMF8090, QCAP8288, BHL8090 and KSSTOCK8090), since they produce practically identical result as the respective initial year indices. Throughout, OLS-estimates and IV-estimates are reported, together with a set of diagnostic tests. A Hausman test of exogeneity tests whether the IV and OLS estimates differ significantly and hence if instrumenting would be necessary in the first place. ${ }^{9}$ An F-test shows whether the instruments explain a great deal of the variation in the instrumented variable, which is desirable. Finally, a Sargan-test of overidentifying restrictions shows whether the instruments have an impact of their own on the dependent variable, which is not desirable.

\subsection{Effects on growth in value added}

Here, we analyze how the liberalization of international capital movements and the integration of capital markets affect industry growth in value added, i.e. the industry-level equivalent to GDP growth, according to equation (2.1).

\section{[Table 2]}

Table 2 reports the first set of our results. Liberalizing capital accounts does not seem to have any direct effects on industry growth in value added. None of the indicators, interacted with the external dependency measure, produce significant results in either the OLS or the IV re-

\footnotetext{
${ }^{8}$ Establishments can principally be treated as firms, although in some cases the collected data underlying the ISY variable was not sufficiently legally strictly defined to eliminate the possibility that establishments are not "plants within one firm".

${ }^{9}$ To be precise, our version of the Hausman test was actually proposed by Davidson-MacKinnon (1993).
} 
gressions. This is also true for the indicators of equity market liberalization and capital market integration. ${ }^{10}$ Another finding is that the strong connection between the level of financial development and growth in value-added, originally suggested by Rajan and Zingales (1998), is robust to controlling for financial liberalization and integration, as shown by the positive and significant coefficients of the interaction between external dependency and financial development.

In table 3, we test the hypothesis that the level of financial development is of importance for the effect of liberalization and integration on growth. This is done by splitting the sample of countries with respect to the median value of the two measures of financial development. Once more, there seem to be practically no growth effects of financial liberalization or capital market integration except in one single case (KSSTOCK80). ${ }^{11}$ The results hence contradict the evidence of Laeven (2000), suggesting a positive correlation between financial liberalization and growth, given a relatively high level of financial development.

[Table 3 here]

\subsection{Effects on firm creation}

Table 4 reports the results of our tests for a link between financial liberalization as well as financial integration and growth in the number of firms, or firm creation, within industries highly dependent on external financing. Neither liberalization nor integration categories produce significant coefficient estimates consistent across both the OLS and IV specifications. For IMF80 and the two integrations measures, CAPSTOCK and CAPFLOW, the OLS estimates are positive and significant, but the IV estimates are not. According to the diagnostic tests reported, the IV-estimates should be followed.

\section{[Table 4]}

In table 5, we have split the sample into two groups of countries, either above or below the median level of financial development. The picture is now somewhat different. In countries with a "high" level of financial development there are strong effects on firm creation within

\footnotetext{
${ }^{10}$ The possible exception is the IV result of BHL80, which is weakly significant at the 10-percent level.
} 
industries dependent on external financing. This result holds for most liberalization indicators across both the OLS and the IV specifications. The integration variables only produce positive significant coefficients in the OLS regressions, but since the diagnostic tests (especially Hausman) do not suggest any statistical endogeneity, these results can be accepted all the same. Some potential concerns could be raised when the Sargan tests of overidentifying restrictions are checked, but since the Hausman tests do not indicate that IV regressions are necessary, the positive and significant OLS estimators should suffice for the results to be consistent.

The results seem to stand out clearer when total capitalization rather than accounting standards is used as a proxy for financial development. One interpretation of this diversity is that the different dimensions of financial development really do measure different aspects of the financial system. Whereas accounting standards primarily reflect the quality of information disclosure and investor protection, total capitalization directly corresponds to the size of markets for equity and bank borrowing. To make new foreign capital inflows help new projects and startups overcome some financing constraints, a well-established system of corporate financing might hence be required.

In a more general sense, these findings suggest that more accessible foreign funding helps cash-constrained entrepreneurs active in industries relatively dependent on external financing to establish new firms. Naturally, we cannot tell whether they use the foreign funding directly or that the domestic creditors become keener on investing in new firms, but the final effect is the same. In essence, this result confirms the findings of Laeven (2000) that small firms benefited more from financial liberalization than did large firms since, the latter had access to preferential credit already in the closed system due to favoritism and personal connections.

[Table 5]

\subsection{Effects on growth in output}

In the final set of regressions, reported in tables 6 and 7, we test whether financial liberalization and integration have any effect on real growth in output in externally dependent indus-

\footnotetext{
${ }^{11}$ CAPSTOCK has a positive significant sign in the OLS regression, but an insignificant sign in the IV and since the Hausman test indicates endogeneity, we focus on the IV-results.
} 
tries. As before, the full sample results (reported in table 6) contain no significant coefficients for our parameter of interest, except in the case of BHL80, which is positive and significant. There may hence prevail some positive effects on production after liberalizing equity markets, but not after capital account liberalization or as a result of being integrated in global capital markets.

\section{[Table 6]}

When splitting the sample into two according to financial development, as reported in table 7 , we once more obtain different results than in the full sample case. It is clear that the growth in real output is boosted by the financial liberalization in countries with relatively welldeveloped financial markets, regardless if this is measured by accounting standards or total capitalization or whether OLS or IV estimators are used. BHL80 once more fails to generate significant positive results for the high-development group. The effect on total output - also a relevant welfare indicator - can be linked to the expansion in the number of firms.

\section{[Table 7]}

\subsection{Summing up: a competition or an outsourcing effect?}

Altogether, considering the results reported in Tables 2-7, it seems that for countries at a relatively high level of financial development, there is a clear firm-creation effect from liberalization (Table 5) that translates into a growth effect in output (Table 7), but not into any such effects on the growth of real value added (Table 3). We have not seen any results in previous research pointing in this direction and thus, they are somewhat unexpected and our interpretations are preliminary and tentative.

One explanation consistent with the results presented here is a competition effect. Financial liberalization spurs firm creation. Basic IO-theory teaches us that when new firms enter a market this generally means an increase in competition and aggregate production. Markups, and eventually profits, can decrease for incumbent firms on that market. Hence, while there 
may be more firms on a market, the margins for each firm shrink and industry value-added may be unaffected or even decrease. ${ }^{12}$

Our findings could also be interpreted from the perspective of industrial vertical disintegration and corporate outsourcing. The basic argument would then be as follows. When financial markets become more liberalized, there is an increase in potential funding. This reduces the costs for firms and entrepreneurs of finding financiers. These reduced capital costs for startups and corporate expansions, in turn, influence the choices of existing firms when it comes to considering outsourcing parts of their production to other units. Outsourcing has become less costly and, ceteris paribus, therefore more likely. Outsourcing can yield the observed pattern by breaking up value added chains.

To make the outsourcing argument more clear, consider the following two-period example. In period 1, an industry consists of a single firm producing 100 units of final goods. For this purpose, it first produces 50 intermediate inputs, using zero inputs, and then 100 units of final goods, using these intermediate inputs. For the industry, the firm hence creates a value-added of 100. In the second period, this firm decides to outsource its intermediate production to another firm. A subsidiary firm is set up to produce the 50 units of intermediate inputs that are delivered to the final good producer for its production of the 100 units of final goods. The final good producer has a production of 100 units of final goods but only a value-added of 50, since it uses 50 units of "external" inputs. The subsidiary produces 50 units which is also its value-added. The growth in value-added between period 1 and 2 is therefore zero, but the growth in (measured) output is 50. Further, there is a growth in number of firms. Hence, this simple outsourcing example closely replicates our findings.

Given the data at our disposal, we cannot perform a direct test that discriminates between the two hypotheses put forward above. If, however, price increases are relatively low in sectors where firm creation is high, this yields some, albeit weak, support for the competition hypotheses. In order to recover industry level price series, we need data on value added (or production) in both current and constant prices. These data are not available in the UN ISYdatabase, but do exist for a subset of countries in the STAN-database from the OECD (OECD,

\footnotetext{
${ }^{12}$ Rajan and Zingales (2002) propose an "interest group" theory of financial development where incumbents oppose financial development and deregulation because it breeds competition. The theory predicts that the incumbents' opposition will be weaker when an economy allows both cross-border trade and capital flows.
} 
1998). ${ }^{13}$ To compute the change in producer prices between 1980 and 1990 for each ISIC industry we extract industry price series by dividing value added in current prices by value added in constant prices. The price changes for the 1980's (in percent) are then regressed on the growth rates of firm creation and a set of industry and country dummies.

As can be seen in column 1 of Table 8, there is a positive partial correlation between firm creation and price increases. Since firm creation and increasing prices are expected to go hand in hand if, for example, demand is increasing, we control for growth in value added in the second column. This does not affect the result. In columns 3 and 4, only countries with above median values of total capitalization are included. When not controlling for growth in value added, the positive correlation remains in this subsample, but firm creation is insignificant in the final specification.

[Table 8]

The results in Table 8 point towards an explanation based on outsourcing rather than increased competition. It is important to note, however, that this is an interpretation based on indirect effects at the industry-level. Actual outsourcing decisions are carried out on the firmlevel. To fully analyze the question, we would need more detailed data.

Much of the previous research on explaining the observed increase in global outsourcing in recent decades has primarily focused on technology enhancements and improved contracting environments (see, e.g., Carlsson, 1999; Grossman and Helpman, 2002). Our finding on improved financing opportunities through international financial liberalization hence suggests a partly new research agenda on the links between international financial liberalization and economic development.

\section{Conclusions}

This paper investigates the growth effects of international financial liberalization. While previous work has mainly approached this problem by considering aggregate growth rates, our

\footnotetext{
${ }^{13}$ The countries for which the data overlaps are Austria, Canada, Finland, France, Germany, Greece, Italy, Korea, Mexico, Netherlands, Norway, Portugal, Spain, Sweden, UK, USA. The positive growth effects on production holds in some and the positive growth effects on firm creation holds in most specifications for this sample of countries when total capitalization is above the median value (results available upon request).
} 
paper analyzes the growth effects at the industry level, using the data and methodology developed by Rajan and Zingales (1998).

The results are both interesting and somewhat puzzling. The main result is that industries highly dependent on external financing do not experience a higher growth in value added among countries with liberalized capital accounts or equity markets. The same result holds for countries more integrated with the international capital market in terms of actual capital flows and stocks. Although it is plausible that the growth effects of liberalization and integration differ between countries at different levels of financial development, we cannot draw any conclusions in this direction. We do, however, find significant positive effects of liberalizing capital accounts and equity markets on the creation of new firms and growth in production given that countries have relatively well developed financial markets. ${ }^{14}$ Hence, there may be growth effects of financial liberalization other than in value added. In a dynamic perspective, accelerated firm growth is important for a functioning creative destruction and thereby also for sustained long run economic development.

Increased competition provides a straightforward explanation of these results. Financial liberalization stimulates firm creation, which increases competition and production. Value added, on the other hand, does not increase since the prices of final output fall. A second potential explanation is based of industrial vertical disintegration and corporate outsourcing. When the setting up of new plants is made less expensive by the liberalization of financial markets, firms become more inclined to outsource the parts of their production. Since outsourcing means breaking up value added chains, it could result in a pattern of increased firm creation, increased measured production and zero growth in value added. Some preliminary evidence point towards an explanation based on outsourcing rather than increased competition, but to fully analyze the question more research is needed.

The increase in outsourcing in the last couple of decades has been observed by numerous other authors, but they have primarily explained it by technological or legal determinants and not, as we do, by the effects of reduced costs of corporate financing as a result of financial liberalization. The results on an outsourcing and/or competition effect following financial liberalization and integration open up a new research agenda. To capture the entire range of the

\footnotetext{
${ }^{14}$ It should be noted that the results are somewhat dependent on how financial development is measured. The results using accounting standards are weaker than when total capitalization is used.
} 
effects of liberalized capital accounts and financial integration on domestic economic development, combing cross-country macro data with industry- or firm-level data can be a fruitful approach. 


\section{References}

Alesina, Alberto, Vittorio Grilli, and Gian Maria Milesi-Ferretti (1994) “The Political Economy of Capital Controls" in Leidermann and Razin (eds.), Capital Mobility: The Impact on Consumption, Investment and Growth. Cambridge: CUP.

Arteta, Carlos, Barry Eichengreen and Charles Wyplosz (2001), "When Does Capital Account Liberalization Help More Than It Hurts?”, NBER WP \#8414.

Bekaert, Geert and Campbell Harvey (2000) "Foreign Speculators and Emerging Equity Markets", Journal of Finance, 55:2, 565-613.

Bekaert, Geert, Campbell Harvey and Christian Lundblad (2000) "Emerging Equity Markets and Economic Development", Journal of Development Economics, 66, 465-504.

Bekaert, Geert, Campbell Harvey and Christian Lundblad (2001) "Does financial liberalization spur economic growth?”, NBER WP \#8245.

Carlsson, Bo (1999), "Small Business, Entrepreneurship, and Industrial Dynamics" in: Acs, Z. J. (ed.) Are Small Firms Important? Their Role and Impact, Doredrecht: Kluwer.

Chari, Anusha and Peter Blair Henry (2001) "Capital Account Liberalization: Allocative Efficiency or Animal Spirits?”, mimeo GSB Stanford .

Davidson, Russell and James G. MacKinnon (1993) Estimation and inference in econometrics, New York: Oxford University Press.

Edison, Hali, J., Michael W. Klein, Luca Ricci and Torsten Slok (2002a) "Capital account liberalization and economic performance: survey and synthesis”, NBER WP \#9100.

Edison, Hali, J., Ross Levine, Luca Ricci and Torsten Slok (2002b) "International Finacial Integration and Economic Growth", forthcoming Journal of International Money and Finance.

Edwards, Sebastian (2001) "Capital Mobility and Economic Performance: Are Emerging Economies Different?”, NBER WP \#8076.

Eichengreen, Barry (2001) "Capital Account Liberalization: What Do Cross-Country Studies Tell Us?”, Word Bank Economic Review, 15:3, 341-365.

Grossman, Gene M. and Elhanan Helpman (2002) "Outsourcing in a Global Economy", NBER WP \#8728.

Harrinson, Ann, Inessa Love and Margaret McMillan (2001) "Global Capital Flows and Financing Constraints", World Bank WP \#2782.

Henry, Peter Blair (2000a) "Stock Market Liberalization, Economic Reform, and Emerging Market Equity Prices”, Journal of Finance, 55:2, 529-564. 
Henry, Peter Blair (2000b) "Do Stock Market Liberalizations Cause Investment Booms?", Journal of Financial Economics, 58:1-2, 301-334

International Finance Corporation, Emerging Stock Markets Factbook, Washington D.C.: International Finance Corporation, various years.

International Monetary Fund, International Financial Statistics, Washington D.C.: International Monetary Fund, various years.

Kaminsky, Graciela and Sergio Schmukler (2001) "On Booms and Crashes: Financial Liberalization and Stock Market Cycles”, World Bank WP.

Klein, Michael and Giovanni Olivei (1999) "Capital Account Liberalization, Financial Depth, and Economic Growth”, NBER WP \#7384.

Lane, Philip R. and Gian Maria Milesi-Feretti (2001), "The External wealth of Nations: Measures of Foreign Assets and Liabilities for Industrial and Developing Countries", Journal of International Economics, 55, 263-294.

Laeven, Luc (2000) "Financial Liberalization and Financing Constraints: Evidence from panel Data on Emerging Economies”, World Bank WP \#2467.

Levine, Ross (2001) "International Financial Liberalization and Economic Growth", Review of International Economics, 9:4, 688-704.

Levine, Ross and Sara Zervos (1998) "Capital Control Liberalization and Stock Market Development”, World Development, 26:7, 1169-1183.

OECD (1998), STAN Database for Industrial Analysis 1998, Paris: OECD.

Quinn, Dennis (1997) "The Correlates of Change in International Financial Regulation", American Political Science Review, 91:3, 531-551.

Rajan, Raghuram and Luigi Zingales (1998) "Financial Dependence and Growth", American Economic Review, 88, 559-586.

Rajan, Raghuram and Luigi Zingales (2002) "The Great Reversals: The Politics of Financial Development in the $20^{\text {th }}$ Century", forthcoming Journal of Financial Economics.

Rodrik, Dani (1998) "Who Needs Capital-Account Convertibility?" in "Should the IMF pursue Capital-Account Convertibility?", Essays in International Finance, 207, Princeton University.

United Nations, Statistical Division, Industrial Statistics Yearbook, Vol. I: General Statistics, New York: United Nations, various years.

United Nations Industrial Development Organization (UNIDO), International Yearbook of Industrial Statistics, Vienna: UNIDO, various years.

World Bank, World Development Indicators, Washington D.C.: World Bank, various years. 
Table 1. Summary statistics and correlates

\begin{tabular}{|c|c|c|c|c|c|c|c|c|c|c|c|c|}
\hline & $\begin{array}{l}\text { IMF- } \\
80\end{array}$ & $\begin{array}{l}\text { IMF- } \\
8090\end{array}$ & $\begin{array}{l}\text { QCAP- } \\
82\end{array}$ & $\begin{array}{l}\text { QCAP- } \\
8288\end{array}$ & $\begin{array}{l}\text { BHL- } \\
80\end{array}$ & $\begin{array}{l}\text { BHL- } \\
8090\end{array}$ & $\begin{array}{c}\text { KSSTOCK- } \\
80\end{array}$ & $\begin{array}{c}\text { KSSTOCK- } \\
8090\end{array}$ & CAPSTOCK & CAPFLOW & TOTCAP & ACCSTAN \\
\hline IMF8090 & $\begin{array}{c}0.82 \\
(0.00)\end{array}$ & 1 & & & & & & & & & & \\
\hline QCAP82 & $\begin{array}{c}0.53 \\
(0.00)\end{array}$ & $\begin{array}{c}0.68 \\
(0.00)\end{array}$ & 1 & & & & & & & & & \\
\hline QCAP8288 & $\begin{array}{c}0.44 \\
(0.00)\end{array}$ & $\begin{array}{c}0.66 \\
(0.00)\end{array}$ & $\begin{array}{c}0.96 \\
(0.00)\end{array}$ & 1 & & & & & & & & \\
\hline BHL80 & $\begin{array}{c}0.20 \\
(0.00)\end{array}$ & $\begin{array}{c}0.39 \\
(0.00)\end{array}$ & $\begin{array}{c}0.71 \\
(0.00)\end{array}$ & $\begin{array}{c}0.76 \\
(0.00)\end{array}$ & 1 & & & & & & & \\
\hline BHL8090 & $\begin{array}{c}0.24 \\
(0.00)\end{array}$ & $\begin{array}{c}0.47 \\
(0.00)\end{array}$ & $\begin{array}{c}0.74 \\
(0.00)\end{array}$ & $\begin{array}{c}0.82 \\
(0.00)\end{array}$ & $\begin{array}{c}0.94 \\
(0.00)\end{array}$ & 1 & & & & & & \\
\hline KSSTOCK80 & $\begin{array}{c}0.15 \\
(0.00)\end{array}$ & $\begin{array}{c}0.27 \\
(0.00)\end{array}$ & $\begin{array}{c}0.74 \\
(0.00)\end{array}$ & $\begin{array}{c}0.76 \\
(0.00)\end{array}$ & $\begin{array}{c}0.63 \\
(0.00)\end{array}$ & $\begin{array}{c}0.62 \\
(0.00)\end{array}$ & 1 & & & & & \\
\hline KSSTOCK 8090 & $\begin{array}{c}0.16 \\
(0.00)\end{array}$ & $\begin{array}{c}0.35 \\
(0.00)\end{array}$ & $\begin{array}{c}0.74 \\
(0.00)\end{array}$ & $\begin{array}{c}0.80 \\
(0.00)\end{array}$ & $\begin{array}{c}0.64 \\
(0.00)\end{array}$ & $\begin{array}{c}0.72 \\
(0.00)\end{array}$ & $\begin{array}{c}0.95 \\
(0.00)\end{array}$ & 1 & & & & \\
\hline CAPSTOCK & $\begin{array}{c}0.28 \\
(0.00)\end{array}$ & $\begin{array}{c}0.35 \\
(0.00)\end{array}$ & $\begin{array}{c}0.41 \\
(0.00)\end{array}$ & $\begin{array}{c}0.42 \\
(0.00)\end{array}$ & $\begin{array}{c}0.44 \\
(0.00)\end{array}$ & $\begin{array}{c}0.37 \\
(0.00)\end{array}$ & $\begin{array}{c}0.34 \\
(0.00)\end{array}$ & $\begin{array}{c}0.31 \\
(0.00)\end{array}$ & 1 & & & \\
\hline CAPFLOW & $\begin{array}{c}0.46 \\
(0.00)\end{array}$ & $\begin{array}{c}0.63 \\
(0.00)\end{array}$ & $\begin{array}{c}0.67 \\
(0.00)\end{array}$ & $\begin{array}{c}0.69 \\
(0.00)\end{array}$ & $\begin{array}{c}0.61 \\
(0.00)\end{array}$ & $\begin{array}{c}0.65 \\
(0.00)\end{array}$ & $\begin{array}{c}0.47 \\
(0.00)\end{array}$ & $\begin{array}{c}0.59 \\
(0.00)\end{array}$ & $\begin{array}{c}0.56 \\
(0.00)\end{array}$ & 1 & & \\
\hline TOTCAP & $\begin{array}{c}0.18 \\
(0.00)\end{array}$ & $\begin{array}{c}0.36 \\
(0.00)\end{array}$ & $\begin{array}{c}0.46 \\
(0.00)\end{array}$ & $\begin{array}{c}0.49 \\
(0.00)\end{array}$ & $\begin{array}{c}0.36 \\
(0.00)\end{array}$ & $\begin{array}{c}0.46 \\
(0.00)\end{array}$ & $\begin{array}{c}0.42 \\
(0.00)\end{array}$ & $\begin{array}{c}0.62 \\
(0.00)\end{array}$ & $\begin{array}{c}0.02 \\
(0.48)\end{array}$ & $\begin{array}{c}0.55 \\
(0.00)\end{array}$ & 1 & \\
\hline ACCSTAN & $\begin{array}{c}0.13 \\
(0.00) \\
\end{array}$ & $\begin{array}{c}0.39 \\
(0.00)\end{array}$ & $\begin{array}{c}0.42 \\
(0.00)\end{array}$ & $\begin{array}{c}0.50 \\
(0.00)\end{array}$ & $\begin{array}{c}0.56 \\
(0.00) \\
\end{array}$ & $\begin{array}{c}0.58 \\
(0.00)\end{array}$ & $\begin{array}{c}0.40 \\
(0.00)\end{array}$ & $\begin{array}{c}0.47 \\
(0.00)\end{array}$ & $\begin{array}{c}0.21 \\
(0.00)\end{array}$ & $\begin{array}{c}0.47 \\
(0.00)\end{array}$ & $\begin{array}{c}0.41 \\
(0.00)\end{array}$ & 1 \\
\hline \# Obs & 42 & 42 & 39 & 39 & 42 & 42 & 22 & 22 & 39 & 41 & 41 & 33 \\
\hline Mean & 0.31 & 0.28 & 0.52 & 0.56 & 0.31 & 0.38 & 0.47 & 0.56 & 0.76 & 0.03 & 0.72 & 61.44 \\
\hline Std. Dev. & 0.46 & 0.41 & 0.23 & 0.24 & 0.46 & 0.44 & 0.46 & 0.40 & 0.50 & 0.03 & 0.37 & 13.44 \\
\hline
\end{tabular}

Note and source: IMF80 and IMF8090 are the IMF indicators of an open capital account, for 1980 and the average between 1980-1990. QCAP82 and QCAP8288 are the Quinn (1997) indicators of financial liberalization in the year 1982, and the average of the 1982 and 1988 values. BHL80 and BHL 8090 and KSSTOCK80 and

KSSTOCK8090 are, respectively, the Bekeart et al. (2001) and Kaminsky and Schumkler (2001) indicators of equity market liberalization. CAPSTOCK is the average of the sum of the stock of inward and outward direct investment and the stock of portfolio equity and portfolio debt assets and liabilities, as share of GDP over the period 1980-90,

taken from Lane and Milesi-Feretti (2001). CAPFLOW are the equivalent figures but on flows instead of stocks, collected from the IFS. ACCSTAN = Accounting standards, an index of the quality of each country's information disclosure rules. TOTCAP = Total capitalization, the sum of domestic credits and stock market capitalization, divided by GDP. P-values are in parentheses. 
Table 2: Growth in value added, measures of financial liberalization and integration. Full sample.

\begin{tabular}{|c|c|c|c|c|c|c|c|c|c|c|c|c|}
\hline & \multicolumn{4}{|c|}{ Capital account liberalization measured as: } & \multicolumn{4}{|c|}{ Stock market liberalization measured as: } & \multicolumn{4}{|c|}{ Capital market integration measured as: } \\
\hline & \multicolumn{2}{|c|}{ IMF80 } & \multicolumn{2}{|c|}{ QCAP82 } & \multicolumn{2}{|c|}{ BHL80 } & \multicolumn{2}{|c|}{ KSSTOCK } & \multicolumn{2}{|c|}{ CAPSTOCK } & \multicolumn{2}{|c|}{ CAPFLOW } \\
\hline & OLS & IV & OLS & IV & OLS & IV & OLS & IV & OLS & IV & OLS & IV \\
\hline Industry share & $\begin{array}{c}-0.952 * * * \\
(0.251)\end{array}$ & $\begin{array}{c}-0.580 * * * \\
(0.149)\end{array}$ & $\begin{array}{l}-0.584 * * * \\
(0.151)\end{array}$ & $\begin{array}{c}-0.577 * * * \\
(0.146)\end{array}$ & $\begin{array}{c}-0.963 * * * \\
(0.250)\end{array}$ & $\begin{array}{c}-0.606^{* * *}- \\
(0.148)\end{array}$ & $\begin{array}{c}-0.622 * * * \\
(0.290)\end{array}$ & $\begin{array}{c}-0.625 * * \\
(0.278)\end{array}$ & $\begin{array}{c}-0.585 * * * \\
(0.155)\end{array}$ & $\begin{array}{c}-0.587 * * *- \\
(0.154)\end{array}$ & $\begin{array}{l}-0.951 * * * \\
(0.230)\end{array}$ & $\begin{array}{c}*-0.959 * * * \\
(0.254)\end{array}$ \\
\hline $\begin{array}{l}\text { Ext. Dep. } \times \\
\text { Total capitalization. }\end{array}$ & $\begin{array}{c}0.071 * * * \\
(0.024)\end{array}$ & $\begin{array}{c}0.051 * * * \\
(0.019)\end{array}$ & $\begin{array}{l}0.049 * * \\
(0.025)\end{array}$ & $\begin{array}{l}0.053^{*} \\
(0.029)\end{array}$ & $\begin{array}{c}0.066 * * * \\
(0.025)\end{array}$ & $\begin{array}{l}0.044 * * \\
(0.016)\end{array}$ & $\begin{array}{l}0.040 * * \\
(0.020)\end{array}$ & $\begin{array}{l}0.038 * \\
(0.020)\end{array}$ & $\begin{array}{c}0.052 * * * \\
(0.018)\end{array}$ & $\begin{array}{c}0.052 * * * \\
(0.018)\end{array}$ & $\begin{array}{l}0.065 * * \\
(0.029)\end{array}$ & $\begin{array}{l}0.060 * * \\
(0.026)\end{array}$ \\
\hline Ext. Dep. $\times$ IMF80 & $\begin{array}{c}0.006 \\
(0.014)\end{array}$ & $\begin{array}{c}0.002 \\
(0.014)\end{array}$ & & & & & & & & & & \\
\hline Ext. Dep. $\times$ QCAP82 & & & $\begin{array}{c}0.010 \\
(0.034)\end{array}$ & $\begin{array}{l}-0.003 \\
(0.053)\end{array}$ & & & & & & & & \\
\hline Ext. Dep. $\times$ BHL80 & & & & & $\begin{array}{c}0.017 \\
(0.013)\end{array}$ & $\begin{array}{l}0.023 * \\
(0.013)\end{array}$ & & & & & & \\
\hline Ext. Dep. $\times$ KSSTOCK & & & & & & & $\begin{array}{c}0.007 \\
(0.011)\end{array}$ & $\begin{array}{c}0.011 \\
(0.016)\end{array}$ & & & & \\
\hline Ext. Dep. $\times$ CAPSTOCK & & & & & & & & & $\begin{array}{c}0.009 \\
(0.008)\end{array}$ & $\begin{array}{c}0.011 \\
(0.029)\end{array}$ & & \\
\hline Ext. Dep. $\times$ CAPFLOW & & & & & & & & & & & $\begin{array}{c}0.167 \\
(0.321)\end{array}$ & $\begin{array}{c}0.296 \\
(0.456)\end{array}$ \\
\hline F-test (p-value) & & $419(0.00)$ & & $371(0.00)$ & & $368(0.00)$ & & $188(0.00)$ & & $36(0.00)$ & & $79(0.00)$ \\
\hline Sargan-test (p-value) & & $0.27(0.87)$ & & $0.12(0.73)$ & & $2.20(0.53)$ & & $6.37(0.09)$ & & $3.69(0.30)$ & & $4.98(0.17)$ \\
\hline Hausman-test (p-value) & & $0.01(0.90)$ & & $0.13(0.72)$ & & $1.13(0.29)$ & & $0.10(0.75)$ & & $0.01(0.94)$ & & $0.05(0.82)$ \\
\hline No. of observations & 1152 & 1106 & 1106 & 1106 & 1152 & 1106 & 666 & 666 & 1106 & 1106 & 1116 & 1116 \\
\hline $\mathrm{R}^{2}$ & 0.29 & 0.33 & 0.33 & 0.33 & 0.29 & 0.33 & 0.40 & 0.41 & 0.33 & 0.33 & 0.28 & 0.28 \\
\hline
\end{tabular}

Note: $* * *$ indicates significance at the 1-percent level, ** at the 5-percent level, * at the 10-percent level. The dependent variable is the annual compounded growth rate in real value added for the period 1980-90 for each ISIC industry in each country. "Industry share" is each industry's share of total value added in manufacturing within each country in 1980. "Ext. Dep." is a proxy for external financial dependence from Rajan and Zingales (1998), described in the text. The other variables are described in Table 1 and instruments used in the IV-estimations are reported in the text. Country- and industry fixed effects are not included in the table. F-test of excluded instruments, Sargan-test of overidentifying restrictions and Hausman (or Davidson-MacKinnon) test of exogeneity of the regressors. Heteroskedasticity robust standard errors are in parentheses. 
Table 3: Growth in value added, financial liberalization and integration. Split sample.

\begin{tabular}{|c|c|c|c|c|c|c|c|c|c|c|}
\hline \multirow{2}{*}{$\begin{array}{l}\text { Indicator of } \\
\text { Fin.lib. or } \\
\text { integration }\end{array}$} & \multirow{2}{*}{$\begin{array}{l}\text { Level of } \\
\text { Fin.dev. }\end{array}$} & \multirow[t]{2}{*}{ Model } & \multirow{2}{*}{$\begin{array}{c}\text { Industry } \\
\text { share }\end{array}$} & \multirow{2}{*}{$\begin{array}{l}\text { Ext.dep } \times \\
\text { Fin.dev. }\end{array}$} & \multirow{2}{*}{$\begin{array}{l}\text { Ext.dep } \times \\
\text { Fin.lib.or } \\
\text { integration }\end{array}$} & \multicolumn{3}{|c|}{ Diagnostic tests: } & \multirow[t]{2}{*}{$\mathrm{N}$} & \multirow[t]{2}{*}{$\mathrm{R}^{2}$} \\
\hline & & & & & & $\begin{array}{l}\text { Haus- } \\
\text { man }\end{array}$ & $\mathrm{F}$ & Sargan & & \\
\hline \multirow{4}{*}{ IMF80 } & \multirow[b]{2}{*}{ High } & OLS & $\begin{array}{c}-0.434 * * \\
(0.191)\end{array}$ & $\begin{array}{c}0.064 * * \\
(0.033)\end{array}$ & $\begin{array}{c}0.008 \\
(0.018)\end{array}$ & & & & 622 & 0.31 \\
\hline & & IV & $\begin{array}{c}-0.450^{* *} \\
(0.181)\end{array}$ & $\begin{array}{c}0.056 \\
(0.034) \\
\end{array}$ & $\begin{array}{c}0.019 \\
(0.023)\end{array}$ & $\begin{array}{c}0.78 \\
(0.38) \\
\end{array}$ & $\begin{array}{c}137 \\
(0.00) \\
\end{array}$ & $\begin{array}{c}1.71 \\
(0.43) \\
\end{array}$ & 622 & 0.31 \\
\hline & \multirow[b]{2}{*}{ Low } & OLS & $\begin{array}{c}-1.417 * * * \\
(0.363)\end{array}$ & $\begin{array}{l}0.230^{*} \\
(0.119)\end{array}$ & $\begin{array}{c}0.010 \\
(0.029)\end{array}$ & & & & 530 & 0.34 \\
\hline & & IV & $\begin{array}{c}-0.850 * * * \\
(0.250)\end{array}$ & $\begin{array}{c}0.110 \\
(0.070)\end{array}$ & $\begin{array}{c}-0.011 \\
(0.025)\end{array}$ & $\begin{array}{c}0.01 \\
(0.94)\end{array}$ & $\begin{array}{c}663 \\
(0.00) \\
\end{array}$ & $\begin{array}{c}0.41 \\
(0.93) \\
\end{array}$ & 484 & 0.39 \\
\hline \multirow{4}{*}{ QCAP82 } & \multirow[b]{2}{*}{ High } & OLS & $\begin{array}{c}-0.434^{* *} \\
(0.187)\end{array}$ & $\begin{array}{c}0.068 * * \\
(0.029)\end{array}$ & $\begin{array}{c}0.011 \\
(0.047)\end{array}$ & & & & 622 & 0.31 \\
\hline & & IV & $\begin{array}{c}-0.451 * * * \\
(0.175)\end{array}$ & $\begin{array}{c}0.065^{*} * \\
(0.030)\end{array}$ & $\begin{array}{c}0.032 \\
(0.076)\end{array}$ & $\begin{array}{c}0.22 \\
(0.64)\end{array}$ & $\begin{array}{c}203 \\
(0.00)\end{array}$ & $\begin{array}{c}0.55 \\
(0.46)\end{array}$ & 622 & 0.31 \\
\hline & \multirow[b]{2}{*}{ Low } & OLS & $\begin{array}{c}-0.861 * * * \\
(0.271)\end{array}$ & $\begin{array}{l}0.119 * \\
(0.065)\end{array}$ & $\begin{array}{c}0.039 \\
(0.048)\end{array}$ & & & & 484 & 0.39 \\
\hline & & IV & $\begin{array}{c}-0.846 * * * \\
(0.252)\end{array}$ & $\begin{array}{c}0.126^{* *} \\
(0.061)\end{array}$ & $\begin{array}{l}-0.025 \\
(0.084)\end{array}$ & $\begin{array}{c}0.75 \\
(0.39)\end{array}$ & $\begin{array}{c}195 \\
(0.00)\end{array}$ & $\begin{array}{c}0.11 \\
(0.74)\end{array}$ & 484 & 0.39 \\
\hline \multirow{4}{*}{ BHL80 } & \multirow[b]{2}{*}{ High } & OLS & $\begin{array}{c}-0.431^{* *} \\
(0.192)\end{array}$ & $\begin{array}{c}0.070 * * * \\
(0.025)\end{array}$ & $\begin{array}{c}0.003 \\
(0.015)\end{array}$ & & & & 622 & 0.31 \\
\hline & & IV & $\begin{array}{c}-0.457^{* *} \\
(0.190)\end{array}$ & $\begin{array}{c}0.072 * * * \\
(0.025)\end{array}$ & $\begin{array}{c}0.016 \\
(0.011)\end{array}$ & $\begin{array}{c}1.34 \\
(0.25)\end{array}$ & $\begin{array}{c}340 \\
(0.00)\end{array}$ & $\begin{array}{c}6.15 \\
(0.10)\end{array}$ & 622 & 0.31 \\
\hline & \multirow[b]{2}{*}{ Low } & OLS & $\begin{array}{c}-1.427 * * * \\
(0.362)\end{array}$ & $\begin{array}{c}0.046^{* * *} \\
(0.015)\end{array}$ & $\begin{array}{c}0.038 \\
(0.023)\end{array}$ & & & & 530 & 0.34 \\
\hline & & IV & $\begin{array}{c}-0.868 * * * \\
(0.252)\end{array}$ & $\begin{array}{c}0.074 \\
(0.080)\end{array}$ & $\begin{array}{c}0.039 \\
(0.032)\end{array}$ & $\begin{array}{c}0.03 \\
(0.87)\end{array}$ & $\begin{array}{c}147 \\
(0.00)\end{array}$ & $\begin{array}{c}2.86 \\
(0.41)\end{array}$ & 484 & 0.40 \\
\hline \multirow{4}{*}{$\begin{array}{l}\text { KS- } \\
\text { STOCK } 80\end{array}$} & \multirow[b]{2}{*}{ High } & OLS & $\begin{array}{c}-0.416^{* *} \\
(0.206)\end{array}$ & $\begin{array}{l}0.051^{*} \\
(0.031)\end{array}$ & $\begin{array}{c}0.030^{* *} \\
(0.012)\end{array}$ & & & & 368 & 0.49 \\
\hline & & IV & $\begin{array}{c}-0.418 * * \\
(0.192)\end{array}$ & $\begin{array}{l}0.052 * \\
(0.031)\end{array}$ & $\begin{array}{c}0.031 * * \\
(0.014)\end{array}$ & $\begin{array}{c}0.02 \\
(0.90)\end{array}$ & $\begin{array}{c}171 \\
(0.00)\end{array}$ & $\begin{array}{c}3.86 \\
(0.28)\end{array}$ & 368 & 0.49 \\
\hline & \multirow[b]{2}{*}{ Low } & OLS & $\begin{array}{c}-1.067^{*} \\
(0.578)\end{array}$ & $\begin{array}{c}0.204^{* * *} * \\
(0.071)\end{array}$ & $\begin{array}{l}-0.007 \\
(0.025)\end{array}$ & & & & 298 & 0.43 \\
\hline & & IV & $\begin{array}{c}-1.076^{* *} \\
(0.531)\end{array}$ & $\begin{array}{c}0.204 * * * \\
(0.066)\end{array}$ & $\begin{array}{l}-0.007 \\
(0.033)\end{array}$ & $\begin{array}{c}0.00 \\
(0.98) \\
\end{array}$ & $\begin{array}{c}932 \\
(0.00)\end{array}$ & $\begin{array}{c}0.28 \\
(0.96)\end{array}$ & 298 & 0.43 \\
\hline
\end{tabular}

...continues on next page. 
Table 3 (continued)

\begin{tabular}{|c|c|c|c|c|c|c|c|c|c|c|}
\hline \multirow{2}{*}{$\begin{array}{l}\text { Indicator of } \\
\text { Fin.lib. or } \\
\text { integration }\end{array}$} & \multirow{2}{*}{$\begin{array}{l}\text { Level of } \\
\text { Fin.dev. }\end{array}$} & \multirow[t]{2}{*}{ Model } & \multirow{2}{*}{$\begin{array}{l}\text { Industry } \\
\text { share }\end{array}$} & \multirow{2}{*}{$\begin{array}{l}\text { Ext.dep } \times \\
\text { Fin.dev. }\end{array}$} & \multirow{2}{*}{$\begin{array}{l}\text { Ext.dep } \times \\
\text { Fin.lib.or } \\
\text { integration }\end{array}$} & \multicolumn{3}{|c|}{ Diagnostic tests: } & \multirow[t]{2}{*}{$\mathrm{N}$} & \multirow[t]{2}{*}{$\mathrm{R}^{2}$} \\
\hline & & & & & & $\begin{array}{l}\text { Haus- } \\
\text { man }\end{array}$ & $\mathrm{F}$ & Sargan & & \\
\hline \multirow{4}{*}{$\begin{array}{l}\text { CAP- } \\
\text { STOCK }\end{array}$} & \multirow[b]{2}{*}{ High } & OLS & $\begin{array}{c}-0.450 * * \\
(0.204)\end{array}$ & $\begin{array}{c}0.080 * * * \\
(0.029)\end{array}$ & $\begin{array}{c}0.017 * \\
(0.009)\end{array}$ & & & & 622 & 0.32 \\
\hline & & IV & $\begin{array}{c}-0.400^{* *} \\
(0.189)\end{array}$ & $\begin{array}{c}0.058^{* *} \\
(0.025)\end{array}$ & $\begin{array}{l}-0.017 \\
(0.016)\end{array}$ & $\begin{array}{c}3.85 \\
(0.05)\end{array}$ & $\begin{array}{c}81 \\
(0.00)\end{array}$ & $\begin{array}{c}2.03 \\
(0.57)\end{array}$ & 622 & 0.30 \\
\hline & \multirow[b]{2}{*}{ Low } & OLS & $\begin{array}{c}-0.850 * * * \\
(0.266)\end{array}$ & $\begin{array}{c}0.132 * * \\
(0.066)\end{array}$ & $\begin{array}{l}-0.017 \\
(0.037)\end{array}$ & & & & 484 & 0.39 \\
\hline & & IV & $\begin{array}{r}-0.100 \\
(0.162)\end{array}$ & $\begin{array}{c}0.185 * * * \\
(0.057)\end{array}$ & $\begin{array}{c}0.027 \\
(0.020)\end{array}$ & $\begin{array}{c}0.93 \\
(0.34)\end{array}$ & $\begin{array}{c}140 \\
(0.00)\end{array}$ & $\begin{array}{c}3.62 \\
(0.16)\end{array}$ & & 0.48 \\
\hline \multirow{4}{*}{$\begin{array}{l}\text { CAP- } \\
\text { FLOW }\end{array}$} & \multirow[b]{2}{*}{ High } & OLS & $\begin{array}{c}-0.420 * * \\
(0.188)\end{array}$ & $\begin{array}{c}0.071 * * \\
(0.022)\end{array}$ & $\begin{array}{l}-0.037 \\
(0.345)\end{array}$ & & & & 622 & 0.31 \\
\hline & & IV & $\begin{array}{c}-0.403 * * \\
(0.189)\end{array}$ & $\begin{array}{c}0.058^{* *} \\
(0.024)\end{array}$ & $\begin{array}{l}-0.017 \\
(0.026)\end{array}$ & $\begin{array}{c}0.31 \\
(0.58)\end{array}$ & $\begin{array}{c}208 \\
(0.00)\end{array}$ & $\begin{array}{c}2.69 \\
(0.44)\end{array}$ & 622 & 0.31 \\
\hline & \multirow[b]{2}{*}{ Low } & OLS & $\begin{array}{c}-1.446 * * * \\
(0.391)\end{array}$ & $\begin{array}{l}0.201 * * \\
(0.101)\end{array}$ & $\begin{array}{c}0.571 \\
(0.582)\end{array}$ & & & & 494 & 0.21 \\
\hline & & IV & $\begin{array}{c}-1.463 * * * \\
(0.371)\end{array}$ & $\begin{array}{c}0.118 \\
(0.074)\end{array}$ & $\begin{array}{c}2.274 \\
(1.642)\end{array}$ & $\begin{array}{c}1.47 \\
(0.23)\end{array}$ & $\begin{array}{c}72 \\
(0.00)\end{array}$ & $\begin{array}{c}2.59 \\
(0.46)\end{array}$ & 494 & 0.33 \\
\hline
\end{tabular}

Note: $* * *$ indicates significance at the 1-percent level, ** at the 5-percent level, $*$ at the 10 -percent level. The dependent variable is the annual compounded growth rate in the number of establishments for the period 198090 for each ISIC industry in each country. "Fin.lib." represents the liberalization-indicator of either the capital account or the stock market. "Fin.dev." is financial development as measured by total capitalization. See Table 2 for a description of the rest of the variables. "High" ("Low") financial development refers to countries with above (below) median total capitalization. Heteroskedasticity robust standard errors are in parentheses, except for the diagnostic tests where p-values are reported. 
Table 4: Firm creation, measures of financial liberalization and integration, Full sample.

\begin{tabular}{|c|c|c|c|c|c|c|c|c|c|c|c|c|}
\hline & \multicolumn{4}{|c|}{ Capital account liberalization measured as: } & \multicolumn{4}{|c|}{ Stock market liberalization measured as: } & \multicolumn{4}{|c|}{ Capital market integration measured as: } \\
\hline & \multicolumn{2}{|c|}{ IMF80 } & \multicolumn{2}{|c|}{ QCAP82 } & \multicolumn{2}{|c|}{ BHL80 } & \multicolumn{2}{|c|}{ KSSTOCK } & \multicolumn{2}{|c|}{ CAPSTOCK } & \multicolumn{2}{|c|}{ CAPFLOW } \\
\hline & OLS & IV & OLS & IV & OLS & IV & OLS & IV & OLS & IV & OLS & IV \\
\hline Industry share & $\begin{array}{c}-0.264 * \\
(0.152)\end{array}$ & $\begin{array}{c}-0.374 * * * \\
(0.139)\end{array}$ & $\begin{array}{c}-0.380 * * * \\
(0.189)\end{array}$ & $\begin{array}{c}-0.384 * * * \\
(0.142)\end{array}$ & $\begin{array}{l}-0.257^{*} \\
(0.153)\end{array}$ & $\begin{array}{c}-0.378 * * * \\
(0.139)\end{array}$ & $\begin{array}{l}-0.192 \\
(0.151)\end{array}$ & $\begin{array}{l}-0.198 \\
(0.143)\end{array}$ & $\begin{array}{c}-0.365^{* *} \\
(0.144)\end{array}$ & $\begin{array}{c}-0.356^{* * *} \\
(0.138)\end{array}$ & $\begin{array}{c}-0.268^{*} \\
(0.161)\end{array}$ & $\begin{array}{l}-0.226 \\
(0.151)\end{array}$ \\
\hline $\begin{array}{l}\text { Ext. Dep. } \times \\
\text { Total capitalization. }\end{array}$ & $\begin{array}{l}0.022 * \\
(0.016)\end{array}$ & $\begin{array}{l}0.022 * \\
(0.012)\end{array}$ & $\begin{array}{c}0.015 \\
(0.014)\end{array}$ & $\begin{array}{c}0.013 \\
(0.015)\end{array}$ & $\begin{array}{c}0.027 * * \\
(0.013)\end{array}$ & $\begin{array}{c}0.020 \\
(0.013)\end{array}$ & $\begin{array}{l}0.042 * * \\
(0.020)\end{array}$ & $\begin{array}{l}0.038^{*} \\
(0.018)\end{array}$ & $\begin{array}{l}0.025 * * \\
(0.012)\end{array}$ & $\begin{array}{l}0.029 * * \\
(0.012)\end{array}$ & $\begin{array}{c}0.014 \\
(0.015)\end{array}$ & $\begin{array}{l}0.052 * \\
(0.029)\end{array}$ \\
\hline Ext. Dep. $\times$ IMF80 & $\begin{array}{l}0.021 * * \\
(0.010)\end{array}$ & $\begin{array}{c}0.013 \\
(0.012)\end{array}$ & & & & & & & & & & \\
\hline Ext. Dep. $\times$ QCAP82 & & & $\begin{array}{c}0.034 \\
(0.021)\end{array}$ & $\begin{array}{c}0.042 \\
(0.034)\end{array}$ & & & & & & & & \\
\hline Ext. Dep. $\times$ BHL80 & & & & & $\begin{array}{c}0.009 \\
(0.009)\end{array}$ & $\begin{array}{c}0.016 \\
(0.012)\end{array}$ & & & & & & \\
\hline Ext. Dep. $\times$ KSSTOCK & & & & & & & $\begin{array}{c}0.003 \\
(0.010)\end{array}$ & $\begin{array}{c}0.015 \\
(0.014)\end{array}$ & & & & \\
\hline Ext. Dep. $\times$ CAPSTOCK & & & & & & & & & $\begin{array}{l}0.013 * \\
(0.007)\end{array}$ & $\begin{array}{l}-0.032 \\
(0.021)\end{array}$ & & \\
\hline Ext. Dep. $\times$ CAPFLOW & & & & & & & & & & & $\begin{array}{c}0.333 * * \\
(0.166)\end{array}$ & $\begin{array}{l}-0.441 \\
(0.445)\end{array}$ \\
\hline F-test (p-value) & & $322(0.00)$ & & $300(0.00)$ & & $304(0.00)$ & & $157(0.00)$ & & $30(0.00)$ & & $52(0.00)$ \\
\hline Sargan-test (p-value) & & $0.54(0.76)$ & & $0.01(0.91)$ & & $3.63(0.30)$ & & $3.92(0.27)$ & & $8.34(0.04)$ & & $5.52(0.14)$ \\
\hline Hausman-test (p-value) & & $1.09(0.30)$ & & $0.06(0.81)$ & & $0.31(0.58)$ & & $0.80(0.37)$ & & $3.55(0.06)$ & & $2.72(0.10)$ \\
\hline No. of observations & 1034 & 986 & 986 & 986 & 1034 & 732 & 598 & 598 & 986 & 986 & 998 & 998 \\
\hline $\mathrm{R}^{2}$ & 0.46 & 0.47 & 0.47 & 0.47 & 0.45 & 0.47 & 0.47 & 0.47 & 0.47 & 0.46 & 0.46 & 0.45 \\
\hline
\end{tabular}

Note: $* * *$ indicates significance at the 1-percent level, ** at the 5-percent level, * at the 10-percent level.The dependent variable is the annual compounded growth rate in real output for the period 1980-90 for each ISIC industry in each country. See Table 2 for a description of the rest of the variables. Heteroskedasticity robust standard errors are in parentheses, except for the diagnostic tests where p-values are reported. 
Table 5: Firm creation, financial liberalization and integration. Split sample.

\begin{tabular}{|c|c|c|c|c|c|c|c|c|c|c|}
\hline \multirow{2}{*}{$\begin{array}{l}\text { Indicator of } \\
\text { Fin.lib. or } \\
\text { integration }\end{array}$} & \multirow{2}{*}{$\begin{array}{l}\text { Level of } \\
\text { Fin.dev. }\end{array}$} & \multirow[t]{2}{*}{ Model } & \multirow{2}{*}{$\begin{array}{c}\text { Industry } \\
\text { share }\end{array}$} & \multirow{2}{*}{$\begin{array}{l}\text { Ext.dep } \times \\
\text { Fin.dev. }\end{array}$} & \multirow{2}{*}{$\begin{array}{c}\text { Ext.dep } \times \\
\text { Fin.lib.or } \\
\text { integration }\end{array}$} & \multicolumn{3}{|c|}{ Diagnostic tests: } & \multirow[t]{2}{*}{$\mathrm{N}$} & \multirow[t]{2}{*}{$\mathrm{R}^{2}$} \\
\hline & & & & & & $\begin{array}{c}\text { Haus- } \\
\text { man }\end{array}$ & $F$ & Sargan & & \\
\hline \multirow{6}{*}{ IMF80 } & \multirow{3}{*}{ High } & OLS & $\begin{array}{l}-0.388 \\
(0.264)\end{array}$ & $\begin{array}{c}0.006 \\
(0.018)\end{array}$ & $\begin{array}{c}0.039 * * * \\
(0.013)\end{array}$ & & & & 530 & 0.33 \\
\hline & & & & & & & & & & \\
\hline & & IV & $\begin{array}{l}-0.410 \\
(0.253)\end{array}$ & $\begin{array}{l}-0.010 \\
(0.020)\end{array}$ & $\begin{array}{c}0.057 * * * \\
(0.019)\end{array}$ & $\begin{array}{c}2.49 \\
(0.11)\end{array}$ & $\begin{array}{c}112 \\
(0.00)\end{array}$ & $\begin{array}{c}5.91 \\
(0.05)\end{array}$ & 530 & 0.33 \\
\hline & \multirow{3}{*}{ Low } & OLS & $\begin{array}{l}-0.100 \\
(0.162)\end{array}$ & $\begin{array}{c}0.185 * * * \\
(0.057)\end{array}$ & $\begin{array}{c}0.027 \\
(0.020)\end{array}$ & & & & 504 & 0.54 \\
\hline & & & & & & & & & & \\
\hline & & IV & $\begin{array}{c}-0.273 * * \\
(0.136)\end{array}$ & $\begin{array}{c}0.207 * * * \\
(0.063)\end{array}$ & $\begin{array}{c}0.042 \\
(0.027)\end{array}$ & $\begin{array}{c}1.62 \\
(0.20)\end{array}$ & $\begin{array}{c}394 \\
(0.00)\end{array}$ & $\begin{array}{c}7.85 \\
(0.02)\end{array}$ & 456 & 0.57 \\
\hline \multirow{5}{*}{ QCAP82 } & \multirow[b]{2}{*}{ High } & OLS & $\begin{array}{l}-0.404 \\
(0.274)\end{array}$ & $\begin{array}{c}0.025 \\
(0.018)\end{array}$ & $\begin{array}{c}0.065^{*} * \\
(0.029)\end{array}$ & & & & 530 & 0.32 \\
\hline & & IV & $\begin{array}{c}-0.506 * \\
(0.265)\end{array}$ & $\begin{array}{c}0.003 \\
(0.018)\end{array}$ & $\begin{array}{c}0.173 * * * \\
(0.055)\end{array}$ & $\begin{array}{c}4.31 \\
(0.04)\end{array}$ & $\begin{array}{c}115 \\
(0.00)\end{array}$ & $\begin{array}{c}2.64 \\
(0.10)\end{array}$ & 530 & 0.31 \\
\hline & \multirow{3}{*}{ Low } & OLS & $\begin{array}{c}-0.268^{*} \\
(0.153)\end{array}$ & $\begin{array}{c}0.146 * * * \\
(0.047)\end{array}$ & $\begin{array}{c}0.003 \\
(0.034)\end{array}$ & & & & 456 & 0.57 \\
\hline & & & & & & & & & & \\
\hline & & IV & $\begin{array}{c}-0.272 * * \\
(0.136)\end{array}$ & $\begin{array}{c}0.143 * * * \\
(0.045)\end{array}$ & $\begin{array}{c}0.012 \\
(0.045)\end{array}$ & $\begin{array}{c}0.15 \\
(0.70)\end{array}$ & $\begin{array}{c}333 \\
(0.00)\end{array}$ & $\begin{array}{c}7.88 \\
(0.01)\end{array}$ & 456 & 0.57 \\
\hline \multirow{4}{*}{ BHL80 } & \multirow[b]{2}{*}{ High } & OLS & $\begin{array}{l}-0.366 \\
(0.271)\end{array}$ & $\begin{array}{c}0.039 * * \\
(0.016)\end{array}$ & $\begin{array}{c}0.012 \\
(0.011)\end{array}$ & & & & 530 & 0.32 \\
\hline & & IV & $\begin{array}{c}-0.388 \\
(0.252)\end{array}$ & $\begin{array}{c}0.039 * * \\
(0.016)\end{array}$ & $\begin{array}{c}0.023 * * \\
(0.011)\end{array}$ & $\begin{array}{c}1.44 \\
(0.23)\end{array}$ & $\begin{array}{c}257 \\
(0.00)\end{array}$ & $\begin{array}{c}7.49 \\
(0.06)\end{array}$ & 530 & 0.32 \\
\hline & \multirow[b]{2}{*}{ Low } & OLS & $\begin{array}{c}-0.098 \\
(0.161)\end{array}$ & $\begin{array}{c}0.168^{* * *} \\
(0.053)\end{array}$ & $\begin{array}{l}-0.008 \\
(0.015)\end{array}$ & & & & 504 & 0.54 \\
\hline & & IV & $\begin{array}{c}-0.235 * \\
(0.133)\end{array}$ & $\begin{array}{c}0.219 * * * \\
(0.073)\end{array}$ & $\begin{array}{c}-0.063 * \\
(0.033)\end{array}$ & $\begin{array}{c}4.52 \\
(0.03)\end{array}$ & $\begin{array}{c}141 \\
(0.00)\end{array}$ & $\begin{array}{c}5.06 \\
(0.16)\end{array}$ & 456 & 0.56 \\
\hline \multirow{4}{*}{$\begin{array}{l}\text { KS- } \\
\text { STOCK } 80\end{array}$} & \multirow[b]{2}{*}{ High } & OLS & $\begin{array}{c}0.188 \\
(0.248)\end{array}$ & $\begin{array}{c}0.057 \\
(0.038)\end{array}$ & $\begin{array}{c}0.036^{* * *} * \\
(0.014)\end{array}$ & & & & 312 & 0.47 \\
\hline & & IV & $\begin{array}{c}0.175 \\
(0.228)\end{array}$ & $\begin{array}{c}0.059 \\
(0.036)\end{array}$ & $\begin{array}{c}0.042 * * * \\
(0.017)\end{array}$ & $\begin{array}{c}0.60 \\
(0.44)\end{array}$ & $\begin{array}{c}176 \\
(0.00)\end{array}$ & $\begin{array}{c}1.41 \\
(0.70)\end{array}$ & 312 & 0.47 \\
\hline & \multirow[b]{2}{*}{ Low } & OLS & $\begin{array}{l}-0.286 \\
(0.226)\end{array}$ & $\begin{array}{c}0.146^{* * *} \\
(0.051)\end{array}$ & $\begin{array}{c}-0.044^{*} \\
(0.026)\end{array}$ & & & & 286 & 0.49 \\
\hline & & IV & $\begin{array}{l}-0.286 \\
(0.207)\end{array}$ & $\begin{array}{c}0.147 * * * \\
(0.046)\end{array}$ & $\begin{array}{c}-0.043 * \\
(0.022)\end{array}$ & $\begin{array}{c}0.01 \\
(0.92)\end{array}$ & $\begin{array}{c}1091 \\
(0.00)\end{array}$ & $\begin{array}{c}6.55 \\
(0.09) \\
\end{array}$ & 286 & 0.49 \\
\hline
\end{tabular}

...continues on next page. 
Table 5 (continued)

\begin{tabular}{|c|c|c|c|c|c|c|c|c|c|c|}
\hline \multirow{2}{*}{$\begin{array}{l}\text { Indicator of } \\
\text { Fin.lib. or } \\
\text { integration }\end{array}$} & \multirow{2}{*}{$\begin{array}{l}\text { Level of } \\
\text { Fin.dev. }\end{array}$} & \multirow[t]{2}{*}{ Model } & \multirow{2}{*}{$\begin{array}{l}\text { Industry } \\
\text { share }\end{array}$} & \multirow{2}{*}{$\begin{array}{l}\text { Ext.dep } \times \\
\text { Fin.dev. }\end{array}$} & \multirow{2}{*}{$\begin{array}{c}\text { Ext.dep } \times \\
\text { Fin.lib.or } \\
\text { integration }\end{array}$} & \multicolumn{3}{|c|}{ Diagnostic tests: } & \multirow[t]{2}{*}{$\mathrm{N}$} & \multirow[t]{2}{*}{$\mathrm{R}^{2}$} \\
\hline & & & & & & $\begin{array}{l}\text { Haus- } \\
\text { man }\end{array}$ & $\mathrm{F}$ & Sargan & & \\
\hline \multirow{6}{*}{$\begin{array}{l}\text { CAP- } \\
\text { STOCK }\end{array}$} & \multirow{3}{*}{ High } & OLS & $\begin{array}{l}-0.358 \\
(0.263)\end{array}$ & $\begin{array}{c}0.047 * * * \\
(0.016)\end{array}$ & $\begin{array}{c}0.014 * * \\
(0.007)\end{array}$ & & & & 530 & 0.32 \\
\hline & & & & & & & & & & \\
\hline & & IV & $\begin{array}{l}-0.352 \\
(0.253)\end{array}$ & $\begin{array}{c}0.044 * * * \\
(0.014)\end{array}$ & $\begin{array}{c}0.010 \\
(0.012)\end{array}$ & $\begin{array}{c}0.29 \\
(0.59)\end{array}$ & $\begin{array}{c}95 \\
(0.00)\end{array}$ & $\begin{array}{c}1.67 \\
(0.64)\end{array}$ & 530 & 0.32 \\
\hline & \multirow{3}{*}{ Low } & OLS & $\begin{array}{l}-0.269 \\
(0.143)\end{array}$ & $\begin{array}{c}0.130 \\
(0.046)\end{array}$ & $\begin{array}{c}0.027 \\
(0.023)\end{array}$ & & & & 456 & 0.57 \\
\hline & & & & & & & & & & \\
\hline & & IV & $\begin{array}{c}-0.269 * * \\
(0.134)\end{array}$ & $\begin{array}{c}0.129 * * * \\
(0.044)\end{array}$ & $\begin{array}{c}0.029 \\
(0.024)\end{array}$ & $\begin{array}{c}0.02 \\
(0.88)\end{array}$ & $\begin{array}{c}333 \\
(0.00)\end{array}$ & $\begin{array}{c}8.71 \\
(0.04)\end{array}$ & 456 & 0.57 \\
\hline \multirow{4}{*}{$\begin{array}{l}\text { CAP- } \\
\text { FLOW }\end{array}$} & \multirow[b]{2}{*}{ High } & OLS & $\begin{array}{c}-0.392 \\
(0.274)\end{array}$ & $\begin{array}{c}0.018 \\
(0.021)\end{array}$ & $\begin{array}{l}0.389 * \\
(0.212)\end{array}$ & & & & 530 & 0.32 \\
\hline & & IV & $\begin{array}{c}-0.357 \\
(0.259)\end{array}$ & $\begin{array}{c}0.033 \\
(0.023) \\
\end{array}$ & $\begin{array}{c}0.116 \\
(0.244) \\
\end{array}$ & $\begin{array}{c}2.28 \\
(0.13) \\
\end{array}$ & $\begin{array}{c}153 \\
(0.00) \\
\end{array}$ & $\begin{array}{c}1.98 \\
(0.58) \\
\end{array}$ & 530 & 0.32 \\
\hline & \multirow[b]{2}{*}{ Low } & OLS & $\begin{array}{c}-0.073 \\
(0.168)\end{array}$ & $\begin{array}{c}0.160 * * * \\
(0.050)\end{array}$ & $\begin{array}{c}0.036 \\
(0.346)\end{array}$ & & & & 468 & 0.54 \\
\hline & & IV & $\begin{array}{l}-0.081 \\
(0.162)\end{array}$ & $\begin{array}{c}0.119 * * \\
(0.049)\end{array}$ & $\begin{array}{c}0.733 \\
(0.644)\end{array}$ & $\begin{array}{c}1.88 \\
(0.17)\end{array}$ & $\begin{array}{c}85 \\
(0.00)\end{array}$ & $\begin{array}{c}8.81 \\
(0.03)\end{array}$ & 468 & 0.54 \\
\hline
\end{tabular}

Note: $* * *$ indicates significance at the 1-percent level, $* *$ at the 5-percent level, $*$ at the 10 -percent level. The dependent variable is the annual compounded growth rate in the number of establishments for the period 198090 for each ISIC industry in each country. See Tables 2 and 3 for a description of the other variables. "High" ("Low") financial development refers to countries with above (below) median total capitalization. Heteroskedasticity robust standard errors are in parentheses, except for the diagnostic tests where p-values are reported. 
Table 6: Growth in output, financial liberalization and integration. Full sample.

\begin{tabular}{|c|c|c|c|c|c|c|c|c|c|c|c|c|}
\hline & \multicolumn{4}{|c|}{ Capital account liberalization measured as: } & \multicolumn{4}{|c|}{ Stock market liberalization measured as: } & \multicolumn{4}{|c|}{ Capital market integration measured as: } \\
\hline & \multicolumn{2}{|c|}{ IMF80 } & \multicolumn{2}{|c|}{ QCAP82 } & \multicolumn{2}{|c|}{ BHL80 } & \multicolumn{2}{|c|}{ KSSTOCK } & \multicolumn{2}{|c|}{ CAPSTOCK } & \multicolumn{2}{|c|}{ CAPFLOW } \\
\hline & OLS & IV & OLS & IV & OLS & IV & OLS & IV & OLS & IV & OLS & IV \\
\hline Industry share & $\begin{array}{c}-0.328^{* * *} \\
(0.173)\end{array}$ & $\begin{array}{l}-0.356^{* * *}- \\
(0.075)\end{array}$ & $\begin{array}{l}-0.359^{* * *} \\
(0.077)\end{array}$ & $\begin{array}{c}-0.365^{* * *} \\
(0.076)\end{array}$ & $\begin{array}{c}-0.330^{* * *} \\
(0.072)\end{array}$ & $\begin{array}{l}-0.365^{* * *}- \\
(0.976)\end{array}$ & $\begin{array}{c}-0.416^{* * *} \\
(0.124)\end{array}$ & $\begin{array}{c}-0.421^{* * * *} \\
(0.121)\end{array}$ & $\begin{array}{c}-0.346^{* * * *} \\
(0.079)\end{array}$ & $\begin{array}{c}-0.343^{* * *} \\
(0.073)\end{array}$ & $\begin{array}{l}-0.332^{* * *} \\
(0.074)\end{array}$ & $\begin{array}{c}-0.324 * * * \\
(0.072)\end{array}$ \\
\hline $\begin{array}{l}\text { Ext. Dep. } \times \\
\text { Total capitalization. }\end{array}$ & $\begin{array}{c}0.045^{* * *} \\
(0.013)\end{array}$ & $\begin{array}{c}0.053^{* * *} \\
(0.012)\end{array}$ & $\begin{array}{c}0.049 * * * \\
(0.014)\end{array}$ & $\begin{array}{c}0.040^{* * *} \\
(0.013)\end{array}$ & $\begin{array}{c}0.044 * * * \\
(0.014)\end{array}$ & $\begin{array}{c}0.045^{* * *} \\
(0.012)\end{array}$ & $\begin{array}{c}0.067^{* * *} \\
(0.021)\end{array}$ & $\begin{array}{c}0.061 * * * \\
(0.018)\end{array}$ & $\begin{array}{c}0.052 * * * \\
(0.013)\end{array}$ & $\begin{array}{c}0.054 * * * \\
(0.012)\end{array}$ & $\begin{array}{c}0.037 * * * \\
(0.014)\end{array}$ & $\begin{array}{c}0.057 * * * \\
(0.018)\end{array}$ \\
\hline Ext. Dep. × IMF80 & $\begin{array}{c}0.005 \\
(0.009)\end{array}$ & $\begin{array}{c}0.003 \\
(0.010)\end{array}$ & & & & & & & & & & \\
\hline Ext. Dep. × QCAP82 & & & $\begin{array}{c}0.057 \\
(0.020)\end{array}$ & $\begin{array}{c}0.049 \\
(0.031)\end{array}$ & & & & & & & & \\
\hline Ext. Dep. $\times$ BHL80 & & & & & $\begin{array}{c}0.005 \\
(0.009)\end{array}$ & $\begin{array}{l}0.022^{* *} \\
(0.011)\end{array}$ & & & & & & \\
\hline Ext. Dep. $\times$ KSSTOCK & & & & & & & $\begin{array}{c}0.011 \\
(0.010)\end{array}$ & $\begin{array}{c}0.024 \\
(0.016)\end{array}$ & & & & \\
\hline Ext. Dep. $\times$ CAPSTOCK & & & & & & & & & $\begin{array}{c}0.003 \\
(0.006)\end{array}$ & $\begin{array}{l}-0.019 \\
(0.015)\end{array}$ & & \\
\hline Ext. Dep. $\times$ CAPFLOW & & & & & & & & & & & $\begin{array}{l}0.222^{*} \\
(0.135)\end{array}$ & $\begin{array}{l}-0.212 \\
(0.290)\end{array}$ \\
\hline F-test (p-value) & & $444(0.00)$ & & $420(0.00)$ & & $361(0.00)$ & & $159(0.00)$ & & $82(0.00)$ & & $92(0.00)$ \\
\hline Sargan-test (p-value) & & $4.79(0.09)$ & & $1.98(0.16)$ & & $5.12(0.16)$ & & $12.5(0.01)$ & & $2.01(0.57)$ & & $2.78(0.42)$ \\
\hline Hausman-test (p-value) & & $0.31(0.57)$ & & $1.38(0.24)$ & & $3.23(0.07)$ & & $3.23(0.07)$ & & $2.91(0.08)$ & & $2.83(0.09)$ \\
\hline No. of observations & 1223 & 1154 & 1154 & 1154 & 1223 & 1154 & 674 & 674 & 1165 & 1165 & 1187 & 1187 \\
\hline $\mathrm{R}^{2}$ & 0.44 & 0.50 & 0.50 & 0.50 & 0.44 & 0.50 & 0.60 & 0.60 & 0.50 & 0.50 & 0.44 & 0.44 \\
\hline
\end{tabular}

Note: $* * *$ indicates significance at the 1-percent level, ${ }^{* *}$ at the 5-percent level, ${ }^{*}$ at the 10 -percent level. The dependent variable is the annual compounded growth rate in real output for the period 1980-90 for each ISIC industry in each country. See Table 2 for a description of the other variables. Heteroskedasticity robust standard errors are in parentheses, except for the diagnostic tests where p-values are reported. 
Table 7: Growth in output, financial liberalization and integration. Split sample.

\begin{tabular}{|c|c|c|c|c|c|c|c|c|c|c|}
\hline \multirow{2}{*}{$\begin{array}{l}\text { Indicator of } \\
\text { Fin.lib. or } \\
\text { integration }\end{array}$} & \multirow{2}{*}{$\begin{array}{l}\text { Level of } \\
\text { Fin.dev. }\end{array}$} & \multirow[t]{2}{*}{ Model } & \multirow{2}{*}{$\begin{array}{c}\text { Industry } \\
\text { share }\end{array}$} & \multirow{2}{*}{$\begin{array}{l}\text { Ext.dep } \times \\
\text { Fin.dev. }\end{array}$} & \multirow{2}{*}{$\begin{array}{c}\text { Ext.dep } \times \\
\text { Fin.lib.or } \\
\text { integration }\end{array}$} & \multicolumn{3}{|c|}{ Diagnostic tests: } & \multirow[t]{2}{*}{$\mathrm{N}$} & \multirow[t]{2}{*}{$\overline{\mathrm{R}^{2}}$} \\
\hline & & & & & & $\begin{array}{l}\text { Haus- } \\
\text { man }\end{array}$ & $\mathrm{F}$ & Sargan & & \\
\hline \multirow{5}{*}{ IMF80 } & \multirow[b]{2}{*}{ High } & OLS & $\begin{array}{c}-0.511 * * * \\
(0.131)\end{array}$ & $\begin{array}{c}0.046^{* *} \\
(0.019)\end{array}$ & $\begin{array}{c}0.034 * * * \\
(0.013)\end{array}$ & & & & 635 & 0.43 \\
\hline & & IV & $\begin{array}{c}-0.514 * * * \\
(0.215)\end{array}$ & $\begin{array}{c}0.039 * * \\
(0.018)\end{array}$ & $\begin{array}{c}0.044 * * * \\
(0.017)\end{array}$ & $\begin{array}{c}0.93 \\
(0.34) \\
\end{array}$ & $\begin{array}{c}140 \\
(0.00)\end{array}$ & $\begin{array}{c}3.62 \\
(0.16) \\
\end{array}$ & 635 & 0.43 \\
\hline & \multirow{3}{*}{ Low } & OLS & $\begin{array}{c}-0.264 * * * \\
(0.080)\end{array}$ & $\begin{array}{c}0.121 * * \\
(0.060)\end{array}$ & $\begin{array}{l}-0.015 \\
(0.017)\end{array}$ & & & & 588 & 0.47 \\
\hline & & & & & & & & & & \\
\hline & & IV & $\begin{array}{l}-0.283 \\
(0.084)\end{array}$ & $\begin{array}{c}0.177 * * * \\
(0.055)\end{array}$ & $\begin{array}{l}-0.003 \\
(0.016)\end{array}$ & $\begin{array}{c}0.00 \\
(0.99)\end{array}$ & $\begin{array}{c}583 \\
(0.00)\end{array}$ & $\begin{array}{c}2.34 \\
(0.31)\end{array}$ & 519 & 0.57 \\
\hline \multirow{5}{*}{ QCAP82 } & \multirow[b]{2}{*}{ High } & OLS & $\begin{array}{c}-0.520 * * * \\
(0.131)\end{array}$ & $\begin{array}{c}0.065 * * * \\
(0.019)\end{array}$ & $\begin{array}{l}0.045^{*} \\
(0.025)\end{array}$ & & & & 635 & 0.43 \\
\hline & & IV & $\begin{array}{c}-0.554^{* *} \\
(0.131)\end{array}$ & $\begin{array}{c}0.055^{* * *} * \\
(0.018)\end{array}$ & $\begin{array}{c}0.120 * * * \\
(0.044)\end{array}$ & $\begin{array}{c}2.52 \\
(0.11)\end{array}$ & $\begin{array}{c}186 \\
(0.00)\end{array}$ & $\begin{array}{c}0.50 \\
(0.48)\end{array}$ & 635 & 0.42 \\
\hline & \multirow{3}{*}{ Low } & OLS & $\begin{array}{c}-0.286 * * * \\
(0.089)\end{array}$ & $\begin{array}{c}0.184 * * * \\
(0.050)\end{array}$ & $\begin{array}{c}0.036 \\
(0.038)\end{array}$ & & & & 519 & 0.57 \\
\hline & & & & & & & & & & \\
\hline & & IV & $\begin{array}{c}-0.288 * * * \\
(0.084)\end{array}$ & $\begin{array}{c}0.186^{* * *} \\
(0.048)\end{array}$ & $\begin{array}{c}0.060 \\
(0.051)\end{array}$ & $\begin{array}{c}0.37 \\
(0.54)\end{array}$ & $\begin{array}{c}233 \\
(0.00)\end{array}$ & $\begin{array}{c}0.93 \\
(0.33)\end{array}$ & 519 & 0.57 \\
\hline \multirow{4}{*}{ BHL80 } & \multirow[b]{2}{*}{ High } & OLS & $\begin{array}{c}-0.520^{* * *} \\
(0.131)\end{array}$ & $\begin{array}{c}0.071 * * * \\
(0.019)\end{array}$ & $\begin{array}{c}0.002 \\
(0.011)\end{array}$ & & & & 635 & 0.42 \\
\hline & & IV & $\begin{array}{c}-0.520 * * * \\
(0.127)\end{array}$ & $\begin{array}{c}0.074 * * * \\
(0.019)\end{array}$ & $\begin{array}{c}0.016 \\
(0.010)\end{array}$ & $\begin{array}{c}2.61 \\
(0.11)\end{array}$ & $\begin{array}{c}349 \\
(0.00)\end{array}$ & $\begin{array}{c}6.57 \\
(0.09)\end{array}$ & 635 & 0.42 \\
\hline & \multirow[b]{2}{*}{ Low } & OLS & $\begin{array}{c}-0.267 * * * \\
(0.080)\end{array}$ & $\begin{array}{l}0.111^{*} \\
(0.058)\end{array}$ & $\begin{array}{c}0.026 \\
(0.019)\end{array}$ & & & & 588 & 0.47 \\
\hline & & IV & $\begin{array}{c}-0.285 * * * \\
(0.083)\end{array}$ & $\begin{array}{c}0.136^{* * *} * \\
(0.052)\end{array}$ & $\begin{array}{l}0.043^{*} \\
(0.024)\end{array}$ & $\begin{array}{c}1.34 \\
(0.25)\end{array}$ & $\begin{array}{c}180 \\
(0.00)\end{array}$ & $\begin{array}{c}1.33 \\
(0.73)\end{array}$ & 519 & 0.57 \\
\hline \multirow{4}{*}{$\begin{array}{l}\text { KS- } \\
\text { STOCK } 80\end{array}$} & \multirow[b]{2}{*}{ High } & OLS & $\begin{array}{c}-0.519 * * \\
(0.214)\end{array}$ & $\begin{array}{c}0.111 * * * \\
(0.043)\end{array}$ & $\begin{array}{c}0.036^{* * *} \\
(0.013)\end{array}$ & & & & 366 & 0.50 \\
\hline & & IV & $\begin{array}{c}-0.524 * * * \\
(0.202)\end{array}$ & $\begin{array}{c}0.112 * * * \\
(0.042)\end{array}$ & $\begin{array}{c}0.041^{* * *} \\
(0.015)\end{array}$ & $\begin{array}{c}0.25 \\
(0.62)\end{array}$ & $\begin{array}{c}167 \\
(0.00)\end{array}$ & $\begin{array}{c}2.68 \\
(0.44)\end{array}$ & 366 & 0.50 \\
\hline & \multirow[b]{2}{*}{ Low } & OLS & $\begin{array}{c}-0.434 * * \\
(0.172)\end{array}$ & $\begin{array}{c}0.215^{* * *} \\
(0.058)\end{array}$ & $\begin{array}{c}0.009 \\
(0.018)\end{array}$ & & & & 308 & 0.70 \\
\hline & & IV & $\begin{array}{c}-0.433 * * * \\
(0.159)\end{array}$ & $\begin{array}{c}0.214^{* * *} \\
(0.053)\end{array}$ & $\begin{array}{c}0.019 \\
(0.025)\end{array}$ & $\begin{array}{c}0.28 \\
(0.59)\end{array}$ & $\begin{array}{c}155 \\
(0.00)\end{array}$ & $\begin{array}{c}0.99 \\
(0.80)\end{array}$ & 308 & 0.70 \\
\hline
\end{tabular}

...table continues on next page. 
Table 7 (continued)

\begin{tabular}{|c|c|c|c|c|c|c|c|c|c|c|}
\hline \multirow{2}{*}{$\begin{array}{l}\text { Indicator of } \\
\text { Fin.lib. or } \\
\text { integration }\end{array}$} & \multirow{2}{*}{$\begin{array}{l}\text { Level of } \\
\text { Fin.dev. }\end{array}$} & \multirow[t]{2}{*}{ Model } & \multirow{2}{*}{$\begin{array}{c}\text { Industry } \\
\text { share }\end{array}$} & \multirow{2}{*}{$\begin{array}{l}\text { Ext.dep } \times \\
\text { Fin.dev. }\end{array}$} & \multirow{2}{*}{$\begin{array}{c}\text { Ext.dep } \times \\
\text { Fin.lib.or } \\
\text { integration }\end{array}$} & \multicolumn{3}{|c|}{ Diagnostic tests: } & \multirow[t]{2}{*}{$\mathrm{N}$} & \multirow[t]{2}{*}{$\mathrm{R}^{2}$} \\
\hline & & & & & & $\begin{array}{l}\text { Haus- } \\
\text { man }\end{array}$ & $\mathrm{F}$ & Sargan & & \\
\hline \multirow{4}{*}{$\begin{array}{l}\text { CAP- } \\
\text { STOCK }\end{array}$} & \multirow[b]{2}{*}{ High } & OLS & $\begin{array}{c}-0.505 * * * \\
(0.131)\end{array}$ & $\begin{array}{c}0.077 * * * \\
(0.020)\end{array}$ & $\begin{array}{c}0.010 \\
(0.007)\end{array}$ & & & & 635 & 0.42 \\
\hline & & IV & $\begin{array}{c}-0.505 * * * \\
(0.125)\end{array}$ & $\begin{array}{c}0.077 * * * \\
(0.019)\end{array}$ & $\begin{array}{c}0.009 \\
(0.014)\end{array}$ & $\begin{array}{c}95 \\
(0.00) \\
\end{array}$ & $\begin{array}{c}2.84 \\
(0.42) \\
\end{array}$ & $\begin{array}{c}0.01 \\
(0.92) \\
\end{array}$ & 635 & 0.43 \\
\hline & \multirow[b]{2}{*}{ Low } & OLS & $\begin{array}{c}-0.273 * * * \\
(0.085)\end{array}$ & $\begin{array}{c}0.199 * * * \\
(0.055)\end{array}$ & $\begin{array}{l}-0.027 \\
(0.022)\end{array}$ & & & & 530 & 0.57 \\
\hline & & IV & $\begin{array}{c}-0.274 * * * \\
(0.080)\end{array}$ & $\begin{array}{c}0.201 * * * \\
(0.053)\end{array}$ & $\begin{array}{l}-0.030 \\
(0.030)\end{array}$ & $\begin{array}{c}157 \\
(0.00) \\
\end{array}$ & $\begin{array}{c}1.87 \\
(0.60) \\
\end{array}$ & $\begin{array}{c}0.01 \\
(0.91) \\
\end{array}$ & 530 & 0.57 \\
\hline \multirow{4}{*}{$\begin{array}{l}\text { CAP- } \\
\text { FLOW }\end{array}$} & \multirow[b]{2}{*}{ High } & OLS & $\begin{array}{c}-0.511 * * * \\
(0.132)\end{array}$ & $\begin{array}{c}0.060 * * * \\
(0.020)\end{array}$ & $\begin{array}{l}0.257 * \\
(0.146)\end{array}$ & & & & 635 & 0.43 \\
\hline & & IV & $\begin{array}{c}-0.506^{* * *} \\
(0.126)\end{array}$ & $\begin{array}{c}0.066^{* * *} * \\
(0.021)\end{array}$ & $\begin{array}{c}0.121 \\
(0.216)\end{array}$ & $\begin{array}{c}209 \\
(0.00)\end{array}$ & $\begin{array}{c}3.01 \\
(0.39)\end{array}$ & $\begin{array}{c}0.63 \\
(0.43)\end{array}$ & 635 & 0.43 \\
\hline & \multirow[b]{2}{*}{ Low } & OLS & $\begin{array}{c}-0.263 * * * \\
(0.085)\end{array}$ & $\begin{array}{c}0.129 * * \\
(0.058)\end{array}$ & $\begin{array}{c}0.149 \\
(0.425)\end{array}$ & & & & 552 & 0.47 \\
\hline & & IV & $\begin{array}{c}-0.255^{* * *} \\
(0.081)\end{array}$ & $\begin{array}{c}0.203 * * * \\
(0.068)\end{array}$ & $\begin{array}{l}-1.200 \\
(1.181)\end{array}$ & $\begin{array}{c}58 \\
(0.00)\end{array}$ & $\begin{array}{c}1.95 \\
(0.58)\end{array}$ & $\begin{array}{c}1.56 \\
(0.21)\end{array}$ & 552 & 0.46 \\
\hline
\end{tabular}

Note: $* * *$ indicates significance at the 1-percent level, $* *$ at the 5-percent level, $*$ at the 10 -percent level. The dependent variable is the annual compounded growth rate in the number of establishments for the period 198090 for each ISIC industry in each country. See Tables 2 and 3 for a description of the other variables. "High" ("Low") financial development refers to countries with above (below) median total capitalization. Heteroskedasticity robust standard errors are in parentheses, except for the diagnostic tests where p-values are reported. 
Table 8. Explaining changes in price levels

\begin{tabular}{lcccc}
\hline & \multicolumn{3}{c}{$\begin{array}{c}\text { Dependent variable is the percentage change in } \\
\text { industry price levels between 1980 and } 1990 .\end{array}$} \\
\hline Growth in number of establish- & $1.644^{* * *}$ & $1.282^{* *}$ & $2.097^{* * *}$ & 0.205 \\
ments 1980-1990 & $(0.552)$ & $(0.542)$ & $(0.682)$ & $(0.914)$ \\
Growth in value added 1980-1990 & & $\begin{array}{c}1.201^{* * *} \\
(0.449)\end{array}$ & $3.375^{* * *}$ \\
& & & & $(1.322)$ \\
No. of observations & 324 & 323 & 230 & 229 \\
$\mathrm{R}^{2}$ & 0.91 & 0.91 & 0.80 & 0.81 \\
\hline
\end{tabular}

Note: $* * *$ indicates significance at the 1-percent level, $* *$ at the 5-percent level, ${ }^{*}$ at the 10-percent level. The dependent variable is the percentage change in price levels between 1980 and 1990 for each ISIC industry in each country. Country- and industry fixed effects are included but not shown. Heteroskedasticity robust standard errors are in parentheses. 
Table A1. Indicators of liberalization

\begin{tabular}{|c|c|c|c|c|c|c|}
\hline Country & IMF80 & QCAP82 & BHL80 & KSSTOCK80 & CAPSTOCK & CAPFLOW \\
\hline Australia & 0 & .5 & 1 & . & .742694 & .0562806 \\
\hline Austria & 0 & .75 & 1 & . & 1.172527 & .0383822 \\
\hline Bangladesh & 0 &. & 0 & . &. & .0000203 \\
\hline Brazil & 0 & .375 & 0 & .5 & .4665384 & .0083611 \\
\hline Canada & 1 & .75 & 1 & 1 & 1.1765 & .0572943 \\
\hline Chile & 0 & .5 & 0 & 0 & 1.031781 & .0228369 \\
\hline Columbia & 0 & .375 & 0 & 0 & .5325444 & .0147017 \\
\hline Costa Rica & 1 & .375 & 0 & . & 1.21825 & .0235035 \\
\hline Egypt & 0 & .375 & 0 & . & 1.274474 & .0262076 \\
\hline Finland & 0 & .5 & 1 & .5 & .6951951 & .0392009 \\
\hline France & 0 & .625 & 1 & 1 & .8920823 & .0359365 \\
\hline Germany & 1 & 1 & 1 & 1 & .7598786 & .0354987 \\
\hline Greece & 0 & .5 & 0 & . & .0488642 & .0115876 \\
\hline India & 0 & .25 & 0 & . & .1782569 & \\
\hline Indonesia & 1 & .625 & 0 & 0 & .4505696 & .005563 \\
\hline Israel & 0 & .5 & 0 & . & .0612123 & .0266216 \\
\hline Italy & 0 & .75 & 1 & 1 & .5622534 & .0168005 \\
\hline Jamaica & 0 &. & 0 & . & 1.255333 & .0095036 \\
\hline Japan & 1 & .625 & 0 & 0 & .4995376 & .0504401 \\
\hline Jordan & 0 & .375 & 0 & . & 1.004601 & .0109161 \\
\hline Kenya & 0 &. & 0 & . & . & .0062992 \\
\hline Korea & 0 & .5 & 0 & 0 & .4965836 & .0109355 \\
\hline Malaysia & 1 & .5 & 0 & .5 & .5231221 & .0537342 \\
\hline Mexico & 1 & .375 & 0 & 0 & .5225904 & .0200498 \\
\hline Morocco & 0 & .125 & 0 & . & .9217592 & .0039101 \\
\hline Netherlands & 1 & .75 & 1 & . & 1.947572 & .0912627 \\
\hline New Zeeland & 0 & .625 & 0 & . & 1.236027 & .0484484 \\
\hline Nigeria & 0 & .25 & 0 & . &. & .0184015 \\
\hline Norway & 0 & .5 & 1 & 0 & .8998007 & .0466735 \\
\hline Pakistan & 0 & .25 & 0 & . & .470136 & .0053546 \\
\hline Peru & 1 & .375 & 0 & 0 & .6959333 & .0020136 \\
\hline Philippines & 0 & .25 & 0 & 0 & .7374972 & .0080224 \\
\hline Portugal & 0 & .375 & 0 & 0 & .1630504 & .0261469 \\
\hline Sri Lanka & 0 & .125 & 0 & . & .6738331 & .0074351 \\
\hline Singapore & 1 & 1 & 1 & . & .8321908 & .1469173 \\
\hline South Africa & 0 & .375 & 0 & . & .0678706 & .011975 \\
\hline Spain & 0 & .5 & 0 & 1 & .4833221 & .024915 \\
\hline Sweden & 0 & .75 & 1 & 1 & .916338 & .0437282 \\
\hline Turkey & 0 & .25 & 0 & . & .3829049 & .0056955 \\
\hline UK & 1 & 1 & 1 & 1 & 2.664083 & .1067 \\
\hline USA & 1 & 1 & 1 & 1 & .5350813 & .0265935 \\
\hline Venezuela & 1 & .75 & 0 & 1 & .6150251 & .0474498 \\
\hline
\end{tabular}

IMF80 is the IMF indicator of an open capital account for 1980. QCAP82 is the Quinn (1997) indicator of capital account liberalization in the year 1982. BHL80 and KSSTOCK80 are the Bekeart et al. (2001) and Kaminsky and Schumkler (2001) indicators of equity market liberalization. CAPSTOCK is the average of the sum of the stock of inward and outward direct investment, and the stock of portfolio equity and portfolio debt assets and liabilities, as a share of GDP over the period 1980-90, taken from Lane and Milesi-Feretti (2001). CAPFLOW constitute the equivalent figures, but on flows instead of stocks, collected from the IFS. 
Table A2: Growth in value added, measures of financial liberalization and integration, Full sample.

\begin{tabular}{|c|c|c|c|c|c|c|c|c|c|c|c|c|}
\hline & \multicolumn{4}{|c|}{ Capital account liberalization measured as: } & \multicolumn{4}{|c|}{ Stock market liberalization measured as: } & \multicolumn{4}{|c|}{ Capital market integration measured as: } \\
\hline & \multicolumn{2}{|c|}{ IMF80 } & \multicolumn{2}{|c|}{ QCAP82 } & \multicolumn{2}{|c|}{ BHL 80} & \multicolumn{2}{|c|}{ KSSTOCK80 } & \multicolumn{2}{|c|}{ CAPSTOCK } & \multicolumn{2}{|c|}{ CAPFLOW } \\
\hline & OLS & IV & OLS & IV & OLS & IV & OLS & IV & OLS & IV & OLS & IV \\
\hline Industry share & $\begin{array}{l}-0.691 * * * \\
(0.217)\end{array}$ & $\begin{array}{l}-0.688^{* * *}- \\
(0.211)\end{array}$ & $\begin{array}{l}-0.701^{* * *} \\
(0.220)\end{array}$ & $\begin{array}{c}-0.708^{* * *} \\
(0.215)\end{array}$ & $\begin{array}{c}-0.678^{* *} \\
(0.215)\end{array}$ & $\begin{array}{l}-0.687^{* * *} \\
(0.210)\end{array}$ & $\begin{array}{l}-0.638^{* *} \\
(0.282)\end{array}$ & $\begin{array}{c}-0.643^{* *} \\
(0.272)\end{array}$ & $\begin{array}{c}-0.439^{* *} \\
(0.139)\end{array}$ & $\begin{array}{c}-0.438^{* * *}- \\
(0.134)\end{array}$ & $\begin{array}{l}-0.660^{* * *} \\
(0.224)\end{array}$ & $\begin{array}{l}-0.672 * * * \\
(0.216)\end{array}$ \\
\hline $\begin{array}{l}\text { Ext. Dep. } \times \\
\text { Accounting standards }\end{array}$ & $\begin{array}{c}0.150^{* * *} \\
(0.034)\end{array}$ & $\begin{array}{c}0.151^{* * *} \\
(0.032)\end{array}$ & $\begin{array}{c}0.126^{* * *} \\
(0.037)\end{array}$ & $\begin{array}{c}0.119^{* * *} \\
(0.037)\end{array}$ & $\begin{array}{c}0.142 * * * \\
(0.043)\end{array}$ & $\begin{array}{l}0.117^{* *} \\
(0.049)\end{array}$ & $\begin{array}{c}0.168^{* * *} \\
(0.044)\end{array}$ & $\begin{array}{c}0.160 * * * \\
(0.039)\end{array}$ & $\begin{array}{c}0.147^{* * *} \\
(0.035)\end{array}$ & $\begin{array}{c}0.149^{* * *} \\
(0.040)\end{array}$ & $\begin{array}{c}0.136^{* * *} \\
(0.038)\end{array}$ & $\begin{array}{c}0.123 * * * \\
(0.043)\end{array}$ \\
\hline Ext. Dep. × IMF80 & $\begin{array}{c}0.015 \\
(0.011)\end{array}$ & $\begin{array}{c}0.013 \\
(0.015)\end{array}$ & & & & & & & & & & \\
\hline Ext. Dep. $\times$ QCAP82 & & & $\begin{array}{l}0.049 * \\
(0.029)\end{array}$ & $\begin{array}{c}0.061 \\
(0.040)\end{array}$ & & & & & & & & \\
\hline Ext. Dep. $\times$ BHL80 & & & & & $\begin{array}{c}0.007 \\
(0.012)\end{array}$ & $\begin{array}{c}0.019 \\
(0.019)\end{array}$ & & & & & & \\
\hline Ext. Dep. $\times$ KSSTOCK & & & & & & & $\begin{array}{l}-0.004 \\
(0.012)\end{array}$ & $\begin{array}{c}0.002 \\
(0.016)\end{array}$ & & & & \\
\hline Ext. Dep. $\times$ CAPSTOCK & & & & & & & & & $\begin{array}{l}-0.004 \\
(0.006)\end{array}$ & $\begin{array}{l}-0.006 \\
(0.026)\end{array}$ & & \\
\hline Ext. Dep. $\times$ CAPFLOW & & & & & & & & & & & $\begin{array}{c}0.185 \\
(0.198)\end{array}$ & $\begin{array}{c}0.315 \\
(0.297)\end{array}$ \\
\hline Hausman-test (p-value) & & $0.10(0.75)$ & & $0.15(0.70)$ & & $0.63(0.43)$ & & $0.19(0.66)$ & & $0.01(0.94)$ & & $0.35(0.56)$ \\
\hline F-test (p-value) & & $332(0.00)$ & & $400(0.00)$ & & $224(0.00)$ & & $187(0.00)$ & & $28(0.00)$ & & $170(0.00)$ \\
\hline Sargan-test (p-value) & & $2.26(0.32)$ & & $0.39(0.53)$ & & $4.21(0.24)$ & & $0.07(1.00)$ & & $7.16(0.07)$ & & $6.82(0.08)$ \\
\hline No. of observations & 1020 & 1020 & 1020 & 1020 & 1020 & 1020 & 666 & 666 & 995 & 995 & 984 & 984 \\
\hline $\mathrm{R}^{2}$ & 0.35 & 0.43 & 0.35 & 0.43 & 0.35 & 0.43 & 0.41 & 0.48 & 0.42 & 0.52 & 0.34 & 0.42 \\
\hline
\end{tabular}

Note: *** indicates significance at the 1-percent level, ** at the 5-percent level, * at the 10-percent level. The dependent variable is the annual compounded growth rate in real output for the period 1980-90 for each ISIC industry in each country. See Table 2 for a description of the rest of the variables. Heteroskedasticity robust standard errors are in parentheses, except for the diagnostic tests where p-values are reported. 
Table A3: Growth in value added, financial liberalization and integration. Split sample.

\begin{tabular}{|c|c|c|c|c|c|c|c|c|c|c|}
\hline \multirow{2}{*}{$\begin{array}{l}\text { Indicator of } \\
\text { Fin.lib. or } \\
\text { integration }\end{array}$} & \multirow{2}{*}{$\begin{array}{l}\text { Level of } \\
\text { Fin.dev. }\end{array}$} & \multirow[t]{2}{*}{ Model } & \multirow{2}{*}{$\begin{array}{c}\text { Industry } \\
\text { share }\end{array}$} & \multirow{2}{*}{$\begin{array}{l}\text { Ext.dep } \times \\
\text { Fin.dev. }\end{array}$} & \multirow{2}{*}{$\begin{array}{l}\text { Ext.dep } \times \\
\text { Fin.lib.or } \\
\text { integration }\end{array}$} & \multicolumn{3}{|c|}{ Diagnostic tests: } & \multirow[t]{2}{*}{$\mathrm{N}$} & \multirow[t]{2}{*}{$\mathrm{R}^{2}$} \\
\hline & & & & & & $\begin{array}{l}\text { Haus- } \\
\text { man }\end{array}$ & $\mathrm{F}$ & Sargan & & \\
\hline \multirow{5}{*}{ IMF80 } & \multirow[b]{2}{*}{ High } & OLS & $\begin{array}{c}-0.523 * * \\
(0.245)\end{array}$ & $\begin{array}{c}0.244 * * \\
(0.106)\end{array}$ & $\begin{array}{c}0.021 \\
(0.013)\end{array}$ & & & & 413 & 0.45 \\
\hline & & IV & $\begin{array}{c}-0.368 * * * \\
(0.142)\end{array}$ & $\begin{array}{c}0.164 * \\
(0.098)\end{array}$ & $\begin{array}{c}0.036 * \\
(0.021)\end{array}$ & $\begin{array}{c}0.21 \\
(0.65)\end{array}$ & $\begin{array}{c}92 \\
(0.00) \\
\end{array}$ & $\begin{array}{c}7.30 \\
(0.03) \\
\end{array}$ & 419 & 0.51 \\
\hline & \multirow{3}{*}{ Low } & OLS & $\begin{array}{c}-0.887 * * * \\
(0.303)\end{array}$ & $\begin{array}{c}0.161 * * * \\
(0.062)\end{array}$ & $\begin{array}{c}0.011 \\
(0.018)\end{array}$ & & & & 607 & 0.35 \\
\hline & & & & & & & & & & \\
\hline & & IV & $\begin{array}{c}-0.796^{* * *} \\
(0.202)\end{array}$ & $\begin{array}{c}0.175^{* * *} * \\
(0.061)\end{array}$ & $\begin{array}{c}-0.007 \\
(0.015)\end{array}$ & $\begin{array}{c}0.12 \\
(0.73) \\
\end{array}$ & $\begin{array}{c}486 \\
(0.00) \\
\end{array}$ & $\begin{array}{c}4.82 \\
(0.09) \\
\end{array}$ & 595 & 0.47 \\
\hline \multirow{5}{*}{ QCAP82 } & \multirow[b]{2}{*}{ High } & OLS & $\begin{array}{c}-0.487^{* *} \\
(0.247)\end{array}$ & $\begin{array}{l}0.219^{*} \\
(0.113)\end{array}$ & $\begin{array}{c}0.011 \\
(0.034)\end{array}$ & & & & 413 & 0.44 \\
\hline & & IV & $\begin{array}{c}-0.410 * * * \\
(0.154)\end{array}$ & $\begin{array}{l}-0.159 \\
(0.163)\end{array}$ & $\begin{array}{c}0.164 * \\
(0.095)\end{array}$ & $\begin{array}{c}1.79 \\
(0.18)\end{array}$ & $\begin{array}{c}41 \\
(0.00)\end{array}$ & $\begin{array}{c}5.46 \\
(0.02) \\
\end{array}$ & 419 & 0.48 \\
\hline & \multirow{3}{*}{ Low } & OLS & $\begin{array}{c}-0.907 * * * \\
(0.307)\end{array}$ & $\begin{array}{l}0.130 * \\
(0.067)\end{array}$ & $\begin{array}{c}0.068 \\
(0.042)\end{array}$ & & & & 607 & 0.35 \\
\hline & & & & & & & & & & \\
\hline & & IV & $\begin{array}{c}-0.796^{* * *} \\
(0.205)\end{array}$ & $\begin{array}{c}0.177 * * * \\
(0.063)\end{array}$ & $\begin{array}{c}-0.031 \\
(0.043)\end{array}$ & $\begin{array}{c}0.04 \\
(0.83)\end{array}$ & $\begin{array}{c}371 \\
(0.00)\end{array}$ & $\begin{array}{c}1.29 \\
(0.26)\end{array}$ & 595 & 0.47 \\
\hline \multirow{4}{*}{ BHL80 } & \multirow[b]{2}{*}{ High } & OLS & $\begin{array}{c}-0.471^{*} \\
(0.249)\end{array}$ & $\begin{array}{c}0.332 * * \\
(0.165)\end{array}$ & $\begin{array}{l}-0.016 \\
(0.022)\end{array}$ & & & & 413 & 0.44 \\
\hline & & IV & $\begin{array}{c}-0.341 * * \\
(0.141)\end{array}$ & $\begin{array}{l}0.391 * \\
(0.215)\end{array}$ & $\begin{array}{l}-0.043 \\
(0.030)\end{array}$ & $\begin{array}{c}0.24 \\
(0.62)\end{array}$ & $\begin{array}{c}98 \\
(0.00)\end{array}$ & $\begin{array}{c}7.95 \\
(0.05)\end{array}$ & 419 & 0.50 \\
\hline & \multirow[b]{2}{*}{ Low } & OLS & $\begin{array}{c}-0.903 * * * \\
(0.306)\end{array}$ & $\begin{array}{c}0.139 * * \\
(0.066)\end{array}$ & $\begin{array}{c}0.023 \\
(0.017)\end{array}$ & & & & 607 & 0.35 \\
\hline & & IV & $\begin{array}{c}-0.801 * * * \\
(0.205)\end{array}$ & $\begin{array}{c}0.170 * * * \\
(0.061)\end{array}$ & $\begin{array}{c}0.007 \\
(0.024)\end{array}$ & $\begin{array}{c}1.94 \\
(0.16)\end{array}$ & $\begin{array}{c}194 \\
(0.00)\end{array}$ & $\begin{array}{c}2.87 \\
(0.41)\end{array}$ & 595 & 0.47 \\
\hline \multirow{4}{*}{$\begin{array}{l}\text { KS- } \\
\text { STOCK } 80\end{array}$} & \multirow[b]{2}{*}{ High } & OLS & $\begin{array}{c}-0.847^{* *} \\
(0.336)\end{array}$ & $\begin{array}{c}0.278^{* *} \\
(0.124)\end{array}$ & $\begin{array}{l}-0.013 \\
(0.014)\end{array}$ & & & & 307 & 0.52 \\
\hline & & IV & $\begin{array}{c}-0.414 * * * \\
(0.152)\end{array}$ & $\begin{array}{l}-0.007 \\
(0.121)\end{array}$ & $\begin{array}{c}0.022 \\
(0.023)\end{array}$ & $\begin{array}{c}2.17 \\
(0.14)\end{array}$ & $\begin{array}{c}92 \\
(0.00)\end{array}$ & $\begin{array}{c}1.86 \\
(0.60)\end{array}$ & 303 & 0.57 \\
\hline & \multirow[b]{2}{*}{ Low } & OLS & $\begin{array}{c}-0.732 * \\
(0.432)\end{array}$ & $\begin{array}{c}0.196^{* *} \\
(0.090)\end{array}$ & $\begin{array}{c}-0.002 \\
(0.018)\end{array}$ & & & & 359 & 0.43 \\
\hline & & IV & $\begin{array}{c}-0.390 * * \\
(0.166)\end{array}$ & $\begin{array}{c}0.239 * * * \\
(0.070)\end{array}$ & $\begin{array}{c}0.010 \\
(0.017)\end{array}$ & $\begin{array}{c}0.03 \\
(0.85)\end{array}$ & $\begin{array}{c}212 \\
(0.00)\end{array}$ & $\begin{array}{c}2.64 \\
(0.45)\end{array}$ & 339 & 0.65 \\
\hline
\end{tabular}

...continues on next page. 
Table A3 (continued)

\begin{tabular}{|c|c|c|c|c|c|c|c|c|c|c|}
\hline \multirow{2}{*}{$\begin{array}{l}\text { Indicator of } \\
\text { Fin.lib. or } \\
\text { integration }\end{array}$} & \multirow{2}{*}{$\begin{array}{l}\text { Level of } \\
\text { Fin.dev. }\end{array}$} & \multirow[t]{2}{*}{ Model } & \multirow{2}{*}{$\begin{array}{l}\text { Industry } \\
\text { share }\end{array}$} & \multirow{2}{*}{$\begin{array}{l}\text { Ext.dep } \times \\
\text { Fin.dev. }\end{array}$} & \multirow{2}{*}{$\begin{array}{l}\text { Ext.dep } \times \\
\text { Fin.lib.or } \\
\text { integration }\end{array}$} & \multicolumn{3}{|c|}{ Diagnostic tests: } & \multirow[t]{2}{*}{$\mathrm{N}$} & \multirow[t]{2}{*}{$\mathrm{R}^{2}$} \\
\hline & & & & & & $\begin{array}{c}\text { Haus- } \\
\text { man }\end{array}$ & $\mathrm{F}$ & Sargan & & \\
\hline \multirow{6}{*}{$\begin{array}{l}\text { CAP- } \\
\text { STOCK }\end{array}$} & \multirow{3}{*}{ High } & OLS & $\begin{array}{c}-0.475^{*} \\
(0.284)\end{array}$ & $\begin{array}{c}0.266^{* *} \\
(0.115)\end{array}$ & $\begin{array}{l}-0.006 \\
(0.008)\end{array}$ & & & & 413 & 0.44 \\
\hline & & & & & & & & & & \\
\hline & & IV & $\begin{array}{c}-0.341 * * \\
(0.142)\end{array}$ & $\begin{array}{c}0.140 \\
(0.102) \\
\end{array}$ & $\begin{array}{l}-0.001 \\
(0.008)\end{array}$ & $\begin{array}{c}2.31 \\
(0.13)\end{array}$ & $\begin{array}{c}245 \\
(0.00)\end{array}$ & $\begin{array}{c}8.98 \\
(0.03)\end{array}$ & 419 & 0.50 \\
\hline & \multirow{3}{*}{ Low } & OLS & $\begin{array}{c}-0.528 * * * \\
(0.189)\end{array}$ & $\begin{array}{c}0.195 * * * \\
(0.059)\end{array}$ & $\begin{array}{c}0.006 \\
(0.014)\end{array}$ & & & & 582 & 0.43 \\
\hline & & & & & & & & & & \\
\hline & & IV & $\begin{array}{c}-0.542 * * * \\
(0.132)\end{array}$ & $\begin{array}{c}0.161 * * * \\
(0.060)\end{array}$ & $\begin{array}{c}0.004 \\
(0.020) \\
\end{array}$ & $\begin{array}{c}0.68 \\
(0.41) \\
\end{array}$ & $\begin{array}{c}74 \\
(0.00) \\
\end{array}$ & $\begin{array}{c}1.43 \\
(0.70) \\
\end{array}$ & 569 & 0.58 \\
\hline \multirow{5}{*}{$\begin{array}{l}\text { CAP- } \\
\text { FLOW }\end{array}$} & \multirow[b]{2}{*}{ High } & OLS & $\begin{array}{c}-0.510^{* *} \\
(0.252)\end{array}$ & $\begin{array}{c}0.196^{*} \\
(0.108)\end{array}$ & $\begin{array}{c}0.166 \\
(0.212)\end{array}$ & & & & 413 & 0.44 \\
\hline & & IV & $\begin{array}{c}-0.365^{* * *} * \\
(0.139)\end{array}$ & $\begin{array}{c}0.060 \\
(0.100)\end{array}$ & $\begin{array}{l}0.319 * \\
(0.187)\end{array}$ & $\begin{array}{c}2.68 \\
(0.10) \\
\end{array}$ & $\begin{array}{c}594 \\
(0.00) \\
\end{array}$ & $\begin{array}{c}7.56 \\
(0.06) \\
\end{array}$ & 419 & 0.50 \\
\hline & \multirow{3}{*}{ Low } & OLS & $\begin{array}{c}-0.837 * * * \\
(0.384)\end{array}$ & $\begin{array}{c}0.159 * * \\
(0.162)\end{array}$ & $\begin{array}{c}0.286 \\
(0.485)\end{array}$ & & & & 571 & 0.34 \\
\hline & & & & & & & & & & \\
\hline & & IV & $\begin{array}{c}-0.809 * * * \\
(0.211)\end{array}$ & $\begin{array}{c}0.169 * * * \\
(0.061)\end{array}$ & $\begin{array}{c}0.364 \\
(0.565) \\
\end{array}$ & $\begin{array}{c}1.30 \\
(0.25) \\
\end{array}$ & $\begin{array}{c}82 \\
(0.00) \\
\end{array}$ & $\begin{array}{c}3.93 \\
(0.27) \\
\end{array}$ & 559 & 0.58 \\
\hline
\end{tabular}

Note: $* * *$ indicates significance at the 1-percent level, $* *$ at the 5-percent level, $*$ at the 10 -percent level. The dependent variable is the annual compounded growth rate in value added for the period 1980-90 for each ISIC industry in each country. See Tables 2 and 3 for a description of the other variables. "High" ("Low") financial development refers to countries with above (below) median accounting standards. Heteroskedasticity robust standard errors are in parentheses except, for the diagnostic tests where p-values are reported. 
Table A4: Firm creation, measures of financial liberalization and integration, Full sample.

\begin{tabular}{|c|c|c|c|c|c|c|c|c|c|c|c|c|}
\hline & \multicolumn{4}{|c|}{ Capital account liberalization measured as: } & \multicolumn{4}{|c|}{ Stock market liberalization measured as: } & \multicolumn{4}{|c|}{ Capital market integration measured as: } \\
\hline & \multicolumn{2}{|c|}{ IMF80 } & \multicolumn{2}{|c|}{ QCAP82 } & \multicolumn{2}{|c|}{ BHL80 } & \multicolumn{2}{|c|}{ KSSTOCK } & \multicolumn{2}{|c|}{ CAPSTOCK } & \multicolumn{2}{|c|}{ CAPFLOW } \\
\hline & OLS & IV & OLS & IV & OLS & IV & OLS & IV & OLS & IV & OLS & IV \\
\hline Industry share & $\begin{array}{c}-0.378 * * \\
(0.165)\end{array}$ & $\begin{array}{c}-0.376^{* *} \\
(0.162)\end{array}$ & $\begin{array}{c}-0.377^{* *} \\
(0.170)\end{array}$ & $\begin{array}{c}-0.388 * * \\
(0.165)\end{array}$ & $\begin{array}{c}-0.350 * * \\
(0.165)\end{array}$ & $\begin{array}{c}-0.354 * * \\
(0.160)\end{array}$ & $\begin{array}{l}-0.198 \\
(0.148)\end{array}$ & $\begin{array}{l}-0.204 \\
(0.141)\end{array}$ & $\begin{array}{l}-0.163 * \\
(0.095)\end{array}$ & $\begin{array}{l}-0.165^{*} \\
(0.092)\end{array}$ & $\begin{array}{c}-0.384 * * \\
(0.180)\end{array}$ & $\begin{array}{c}-0.370^{* *} \\
(0.170)\end{array}$ \\
\hline $\begin{array}{l}\text { Ext. Dep. } \times \\
\text { Accounting standards }\end{array}$ & $\begin{array}{c}0.077 * * * \\
(0.025)\end{array}$ & $\begin{array}{c}0.078 * * * \\
(0.024)\end{array}$ & $\begin{array}{l}0.052 * \\
(0.029)\end{array}$ & $\begin{array}{c}0.039 \\
(0.030)\end{array}$ & $\begin{array}{l}0.083 * * \\
(0.035)\end{array}$ & $\begin{array}{c}0.059 \\
(0.040)\end{array}$ & $\begin{array}{c}0.127 * * * \\
(0.035)\end{array}$ & $\begin{array}{c}0.103 * * * \\
(0.028)\end{array}$ & $\begin{array}{c}0.071 * * * \\
(0.026)\end{array}$ & $\begin{array}{c}0.088 * * * \\
(0.033)\end{array}$ & $\begin{array}{l}0.054 * \\
(0.028)\end{array}$ & $\begin{array}{l}0.070 * * \\
(0.035)\end{array}$ \\
\hline Ext. Dep. $\times$ IMF80 & $\begin{array}{c}0.026 * * * \\
(0.010)\end{array}$ & $\begin{array}{l}0.024 * \\
(0.014)\end{array}$ & & & & & & & & & & \\
\hline Ext. Dep. $\times$ QCAP82 & & & $\begin{array}{l}0.057 * * \\
(0.028)\end{array}$ & $\begin{array}{l}0.078 * * \\
(0.039)\end{array}$ & & & & & & & & \\
\hline Ext. Dep. $\times$ BHL80 & & & & & $\begin{array}{c}0.002 \\
(0.012)\end{array}$ & $\begin{array}{c}0.015 \\
(0.018)\end{array}$ & & & & & & \\
\hline Ext. Dep. $\times$ KSSTOCK & & & & & & & $\begin{array}{l}-0.006 \\
(0.010)\end{array}$ & $\begin{array}{c}0.013 \\
(0.014)\end{array}$ & & & & \\
\hline Ext. Dep. $\times$ CAPSTOCK & & & & & & & & & $\begin{array}{c}0.010 \\
(0.007)\end{array}$ & $\begin{array}{l}-0.010 \\
(0.020)\end{array}$ & & \\
\hline Ext. Dep. $\times$ CAPFLOW & & & & & & & & & & & $\begin{array}{l}0.322^{*} \\
(0.178)\end{array}$ & $\begin{array}{c}0.169 \\
(0.206)\end{array}$ \\
\hline Hausman-test (p-value) & & $0.04(0.85)$ & & $0.39(0.53)$ & & $0.56(0.45)$ & & $1.48(0.22)$ & & $0.76(0.38)$ & & $0.40(0.53)$ \\
\hline F-test (p-value) & & $317(0.00)$ & & $317(0.00)$ & & $196(0.00)$ & & $146(0.00)$ & & $26(0.00)$ & & $154(0.00)$ \\
\hline Sargan-test (p-value) & & $1.48(0.47)$ & & $0.01(0.93)$ & & $4.29(0.23)$ & & $1.60(0.66)$ & & $8.57(0.04)$ & & $6.02(0.11)$ \\
\hline No. of observations & 936 & 936 & 936 & 936 & 936 & 936 & 598 & 598 & 905 & 905 & 900 & 900 \\
\hline $\mathrm{R}^{2}$ & 0.32 & 0.32 & 0.32 & 0.32 & 0.31 & 0.31 & 0.48 & 0.48 & 0.42 & 0.42 & 0.32 & 0.32 \\
\hline
\end{tabular}

Note: $* * *$ indicates significance at the 1-percent level, $* *$ at the 5-percent level, $*$ at the 10-percent level. The dependent variable is the annual compounded growth rate in real output for the period 1980-90 for each ISIC industry in each country. See Table 2 for a description of the rest of the variables. Heteroskedasticity robust standard errors are in parentheses, except for the diagnostic tests where p-values are reported. 
Table A5: Firm creation, financial liberalization and integration. Split sample.

\begin{tabular}{|c|c|c|c|c|c|c|c|c|c|c|}
\hline \multirow{2}{*}{$\begin{array}{l}\text { Indicator of } \\
\text { Fin.lib. or } \\
\text { integration }\end{array}$} & \multirow{2}{*}{$\begin{array}{l}\text { Level of } \\
\text { Fin.dev. }\end{array}$} & \multirow[t]{2}{*}{ Model } & \multirow{2}{*}{$\begin{array}{c}\text { Industry } \\
\text { share }\end{array}$} & \multirow{2}{*}{$\begin{array}{l}\text { Ext.dep } \times \\
\text { Fin.dev. }\end{array}$} & \multirow{2}{*}{$\begin{array}{c}\text { Ext.dep } \times \\
\text { Fin.lib.or } \\
\text { integration }\end{array}$} & \multicolumn{3}{|c|}{ Diagnostic tests: } & \multirow[t]{2}{*}{$\mathrm{N}$} & \multirow[t]{2}{*}{$\mathrm{R}^{2}$} \\
\hline & & & & & & $\begin{array}{c}\text { Haus- } \\
\text { man }\end{array}$ & $\mathrm{F}$ & Sargan & & \\
\hline \multirow{6}{*}{ IMF80 } & \multirow{3}{*}{ High } & OLS & $\begin{array}{l}-0.093 \\
(0.208)\end{array}$ & $\begin{array}{c}0.138 \\
(0.098)\end{array}$ & $\begin{array}{l}0.023^{*} \\
(0.013)\end{array}$ & & & & 376 & 0.48 \\
\hline & & & & & & & & & & \\
\hline & & IV & $\begin{array}{l}-0.108 \\
(0.195)\end{array}$ & $\begin{array}{l}-0.141 \\
(0.094)\end{array}$ & $\begin{array}{l}0.028^{*} \\
(0.017)\end{array}$ & $\begin{array}{c}0.29 \\
(0.59)\end{array}$ & $\begin{array}{c}214 \\
(0.00)\end{array}$ & $\begin{array}{c}0.91 \\
(0.64)\end{array}$ & 376 & 0.48 \\
\hline & \multirow{3}{*}{ Low } & OLS & $\begin{array}{c}-0.646^{* *} \\
(0.218)\end{array}$ & $\begin{array}{c}0.060 \\
(0.050)\end{array}$ & $\begin{array}{c}0.024 \\
(0.017)\end{array}$ & & & & 560 & 0.26 \\
\hline & & & & & & & & & & \\
\hline & & IV & $\begin{array}{c}-0.646 * * \\
(0.247)\end{array}$ & $\begin{array}{c}0.057 \\
(0.048)\end{array}$ & $\begin{array}{c}0.020 \\
(0.021)\end{array}$ & $\begin{array}{c}0.32 \\
(0.57)\end{array}$ & $\begin{array}{c}562 \\
(0.00)\end{array}$ & $\begin{array}{c}1.55 \\
(0.46)\end{array}$ & 560 & 0.26 \\
\hline \multirow{5}{*}{ QCAP82 } & \multirow[b]{2}{*}{ High } & OLS & $\begin{array}{l}-0.052 \\
(0.221)\end{array}$ & $\begin{array}{c}0.079 \\
(0.111)\end{array}$ & $\begin{array}{c}0.024 \\
(0.037)\end{array}$ & & & & 376 & 0.47 \\
\hline & & IV & $\begin{array}{c}-0.192 \\
(0.220)\end{array}$ & $\begin{array}{c}-0.136 \\
(0.182)\end{array}$ & $\begin{array}{c}0.137 \\
(0.095)\end{array}$ & $\begin{array}{c}1.22 \\
(0.27)\end{array}$ & $\begin{array}{c}26 \\
(0.00) \\
\end{array}$ & $\begin{array}{c}1.21 \\
(0.27)\end{array}$ & 376 & 0.48 \\
\hline & \multirow{3}{*}{ Low } & OLS & $\begin{array}{c}-0.655^{* *} \\
(0.284)\end{array}$ & $\begin{array}{c}0.028 \\
(0.050)\end{array}$ & $\begin{array}{l}0.071 * \\
(0.038)\end{array}$ & & & & 560 & 0.26 \\
\hline & & & & & & & & & & \\
\hline & & IV & $\begin{array}{c}-0.652 * * \\
(0.270)\end{array}$ & $\begin{array}{c}0.032 \\
(0.046)\end{array}$ & $\begin{array}{c}0.055 \\
(0.042)\end{array}$ & $\begin{array}{c}0.28 \\
(0.59)\end{array}$ & $\begin{array}{c}348 \\
(0.00)\end{array}$ & $\begin{array}{c}0.02 \\
(0.88)\end{array}$ & 560 & 0.26 \\
\hline \multirow{4}{*}{ BHL80 } & \multirow[b]{2}{*}{ High } & OLS & $\begin{array}{c}-0.013 \\
(0.208)\end{array}$ & $\begin{array}{l}0.374^{*} \\
(0.201)\end{array}$ & $\begin{array}{c}-0.038 \\
(0.026)\end{array}$ & & & & 376 & 0.48 \\
\hline & & IV & $\begin{array}{l}-0.010 \\
(0.192)\end{array}$ & $\begin{array}{c}0.458 * * \\
(0.097)\end{array}$ & $\begin{array}{c}-0.051 * \\
(0.027)\end{array}$ & $\begin{array}{c}1.39 \\
(0.30)\end{array}$ & $\begin{array}{c}147 \\
(0.00)\end{array}$ & $\begin{array}{c}3.43 \\
(0.33)\end{array}$ & 376 & 0.48 \\
\hline & \multirow[b]{2}{*}{ Low } & OLS & $\begin{array}{c}-0.652 * * \\
(0.283)\end{array}$ & $\begin{array}{c}0.035 \\
(0.048)\end{array}$ & $\begin{array}{c}0.022 \\
(0.016)\end{array}$ & & & & 560 & 0.26 \\
\hline & & IV & $\begin{array}{c}-0.655^{* *} \\
(0.271)\end{array}$ & $\begin{array}{c}0.031 \\
(0.044)\end{array}$ & $\begin{array}{c}0.031 \\
(0.030)\end{array}$ & $\begin{array}{c}0.09 \\
(0.77)\end{array}$ & $\begin{array}{c}151 \\
(0.00)\end{array}$ & $\begin{array}{c}0.93 \\
(0.82)\end{array}$ & 560 & 0.26 \\
\hline \multirow{4}{*}{$\begin{array}{l}\text { KS- } \\
\text { STOCK } 80\end{array}$} & \multirow[b]{2}{*}{ High } & OLS & $\begin{array}{c}0.152 \\
(0.294)\end{array}$ & $\begin{array}{c}0.175 \\
(0.152)\end{array}$ & $\begin{array}{c}-0.007 \\
(0.018)\end{array}$ & & & & 279 & 0.49 \\
\hline & & IV & $\begin{array}{c}0.171 \\
(0.273)\end{array}$ & $\begin{array}{l}-0.134 \\
(0.193)\end{array}$ & $\begin{array}{c}0.047 \\
(0.034)\end{array}$ & $\begin{array}{c}2.35 \\
(0.13)\end{array}$ & $\begin{array}{c}45 \\
(0.00)\end{array}$ & $\begin{array}{c}2.80 \\
(0.42)\end{array}$ & 279 & 0.48 \\
\hline & \multirow[b]{2}{*}{ Low } & OLS & $\begin{array}{l}-0.070 \\
(0.220)\end{array}$ & $\begin{array}{l}0.128 * \\
(0.072)\end{array}$ & $\begin{array}{c}-0.009 \\
(0.016)\end{array}$ & & & & 396 & 0.47 \\
\hline & & IV & $\begin{array}{l}-0.085 \\
(0.207)\end{array}$ & $\begin{array}{l}0.112 * \\
(0.062)\end{array}$ & $\begin{array}{c}0.005 \\
(0.014)\end{array}$ & $\begin{array}{c}0.98 \\
(0.32)\end{array}$ & $\begin{array}{c}196 \\
(0.00)\end{array}$ & $\begin{array}{c}0.24 \\
(0.97)\end{array}$ & 319 & 0.45 \\
\hline
\end{tabular}

...table continues on next page. 
Table A5 (continued)

\begin{tabular}{|c|c|c|c|c|c|c|c|c|c|c|}
\hline \multirow{2}{*}{$\begin{array}{l}\text { Indicator of } \\
\text { Fin.lib. or } \\
\text { integration }\end{array}$} & \multirow{2}{*}{$\begin{array}{l}\text { Level of } \\
\text { Fin.dev. }\end{array}$} & \multirow[t]{2}{*}{ Model } & \multirow{2}{*}{$\begin{array}{l}\text { Industry } \\
\text { share }\end{array}$} & \multirow{2}{*}{$\begin{array}{l}\text { Ext.dep } \times \\
\text { Fin.dev. }\end{array}$} & \multirow{2}{*}{$\begin{array}{c}\text { Ext.dep } \times \\
\text { Fin.lib.or } \\
\text { integration }\end{array}$} & \multicolumn{3}{|c|}{ Diagnostic tests: } & \multirow[t]{2}{*}{$\mathrm{N}$} & \multirow[t]{2}{*}{$\mathrm{R}^{2}$} \\
\hline & & & & & & $\begin{array}{c}\text { Haus- } \\
\text { man }\end{array}$ & $\mathrm{F}$ & Sargan & & \\
\hline \multirow{4}{*}{$\begin{array}{l}\text { CAP- } \\
\text { STOCK }\end{array}$} & \multirow[b]{2}{*}{ High } & OLS & $\begin{array}{l}-0.020 \\
(0.214)\end{array}$ & $\begin{array}{c}0.102 \\
(0.100)\end{array}$ & $\begin{array}{c}0.007 \\
(0.010)\end{array}$ & & & & 376 & 0.47 \\
\hline & & IV & $\begin{array}{l}-0.017 \\
(0.201)\end{array}$ & $\begin{array}{c}0.082 \\
(0.089)\end{array}$ & $\begin{array}{c}0.013 \\
(0.010)\end{array}$ & $\begin{array}{c}1.24 \\
(0.27) \\
\end{array}$ & $\begin{array}{c}436 \\
(0.00) \\
\end{array}$ & $\begin{array}{c}4.31 \\
(0.23) \\
\end{array}$ & 376 & 0.47 \\
\hline & \multirow[b]{2}{*}{ Low } & OLS & $\begin{array}{c}-0.268^{*} \\
(0.137)\end{array}$ & $\begin{array}{l}0.079 * \\
(0.045)\end{array}$ & $\begin{array}{c}0.015 \\
(0.013)\end{array}$ & & & & 529 & 0.38 \\
\hline & & IV & $\begin{array}{c}-0.282^{* *} \\
(0.135)\end{array}$ & $\begin{array}{c}-0.046 \\
(0.108)\end{array}$ & $\begin{array}{r}-0.080 \\
(0.067)\end{array}$ & $\begin{array}{c}1.67 \\
(0.20) \\
\end{array}$ & $\begin{array}{c}7 \\
(0.00) \\
\end{array}$ & $\begin{array}{c}5.22 \\
(0.15) \\
\end{array}$ & 529 & 0.35 \\
\hline \multirow{4}{*}{$\begin{array}{l}\text { CAP- } \\
\text { FLOW }\end{array}$} & \multirow[b]{2}{*}{ High } & OLS & $\begin{array}{l}-0.015 \\
(0.224)\end{array}$ & $\begin{array}{c}0.100 \\
(0.096)\end{array}$ & $\begin{array}{c}0.104 \\
(0.167)\end{array}$ & & & & 376 & 0.47 \\
\hline & & IV & $\begin{array}{l}-0.078 \\
(0.208)\end{array}$ & $\begin{array}{c}0.070 \\
(0.094)\end{array}$ & $\begin{array}{c}0.233 \\
(0.177)\end{array}$ & $\begin{array}{c}3.46 \\
(0.06)\end{array}$ & $\begin{array}{c}1143 \\
(0.00)\end{array}$ & $\begin{array}{c}3.72 \\
(0.29)\end{array}$ & 376 & 0.47 \\
\hline & \multirow[b]{2}{*}{ Low } & OLS & $\begin{array}{c}-0.660 * * \\
(0.313)\end{array}$ & $\begin{array}{c}0.050 \\
(0.046)\end{array}$ & $\begin{array}{c}0.645 \\
(0.430)\end{array}$ & & & & 524 & 0.26 \\
\hline & & IV & $\begin{array}{c}-0.704 * * \\
(0.302)\end{array}$ & $\begin{array}{c}0.072 \\
(0.051)\end{array}$ & $\begin{array}{c}3.534 * * \\
(1.65)\end{array}$ & $\begin{array}{c}4.03 \\
(0.05)\end{array}$ & $\begin{array}{c}30 \\
(0.00)\end{array}$ & $\begin{array}{c}4.23 \\
(0.24)\end{array}$ & 524 & 0.23 \\
\hline
\end{tabular}

Note: $* * *$ indicates significance at the 1-percent level, ** at the 5-percent level, * at the 10-percent level. The dependent variable is the annual compounded growth rate for the number of establishments for the period 198090 for each ISIC industry in each country. See Tables 2 and 3 for a description of the other variables. "High" ("Low") financial development refers to countries with above (below) median accounting standards. Heteroskedasticity robust standard errors are in parentheses, except for the diagnostic tests where p-values are reported. 
Table A6: Growth in output, measures of financial liberalization and integration, Full sample.

\begin{tabular}{|c|c|c|c|c|c|c|c|c|c|c|c|c|}
\hline & \multicolumn{4}{|c|}{ Capital account liberalization measured as: } & \multicolumn{4}{|c|}{ Stock market liberalization measured as: } & \multicolumn{4}{|c|}{ Capital market integration measured as: } \\
\hline & \multicolumn{2}{|c|}{ IMF80 } & \multicolumn{2}{|c|}{ QCAP82 } & \multicolumn{2}{|c|}{ BHL80 } & \multicolumn{2}{|c|}{ KSSTOCK } & \multicolumn{2}{|c|}{ CAPSTOCK } & \multicolumn{2}{|c|}{ CAPFLOW } \\
\hline & OLS & IV & OLS & IV & OLS & IV & OLS & IV & OLS & IV & OLS & IV \\
\hline Industry share & $\begin{array}{c}-0.329 * * * \\
(0.073)\end{array}$ & $\begin{array}{c}-0.577 * * * \\
(0.141)\end{array}$ & $\begin{array}{c}-0.359 * * * \\
(0.078)\end{array}$ & $\begin{array}{c}-0.587 * * * \\
(0.142)\end{array}$ & $\begin{array}{c}-0.330 * * * \\
(0.072)\end{array}$ & $\begin{array}{c}-0.577 * * * \\
(0.141)\end{array}$ & $\begin{array}{c}-0.416^{* * *} \\
(0.124)\end{array}$ & $\begin{array}{c}-0.333 * * * \\
(0.118)\end{array}$ & $\begin{array}{c}-0.400 * * * \\
(0.100)\end{array}$ & $\begin{array}{c}-0.400 * * * \\
(0.097)\end{array}$ & $\begin{array}{c}-0.589 * * * \\
(0.150)\end{array}$ & $\begin{array}{c}-0.601 * * * \\
(0.144)\end{array}$ \\
\hline $\begin{array}{l}\text { Ext. Dep. } \times \\
\text { Total capitalization. }\end{array}$ & $\begin{array}{c}0.045 * * * \\
(0.013)\end{array}$ & $\begin{array}{c}0.162 * * * \\
(0.036)\end{array}$ & $\begin{array}{c}0.049 * * * \\
(0.014)\end{array}$ & $\begin{array}{c}0.139 * * * \\
(0.038)\end{array}$ & $\begin{array}{c}0.044 * * * \\
(0.014)\end{array}$ & $\begin{array}{c}0.165 \\
(0.053)\end{array}$ & $\begin{array}{c}0.067 * * * \\
(0.021)\end{array}$ & $\begin{array}{c}0.188 * * * \\
(0.040)\end{array}$ & $\begin{array}{c}0.160 * * * \\
(0.042)\end{array}$ & $\begin{array}{c}0.153 * * * \\
(0.043)\end{array}$ & $\begin{array}{c}0.150 * * * \\
(0.043)\end{array}$ & $\begin{array}{l}0.111 * * \\
(0.045)\end{array}$ \\
\hline Ext. Dep. $\times$ IMF80 & $\begin{array}{c}0.005 \\
(0.009)\end{array}$ & $\begin{array}{l}-0.001 \\
(0.012)\end{array}$ & & & & & & & & & & \\
\hline Ext. Dep. $\times$ QCAP82 & & & $\begin{array}{c}0.016 \\
(0.020)\end{array}$ & $\begin{array}{c}0.038 \\
(0.037)\end{array}$ & & & & & & & & \\
\hline Ext. Dep. $\times$ BHL80 & & & & & $\begin{array}{c}0.005 \\
(0.009)\end{array}$ & $\begin{array}{l}-0.002 \\
(0.017)\end{array}$ & & & & & & \\
\hline Ext. Dep. $\times$ KSSTOCK & & & & & & & $\begin{array}{c}0.011 \\
(0.010)\end{array}$ & $\begin{array}{c}0.016 \\
(0.017)\end{array}$ & & & & \\
\hline Ext. Dep. $\times$ CAPSTOCK & & & & & & & & & $\begin{array}{l}-0.007 \\
(0.007)\end{array}$ & $\begin{array}{c}0.001 \\
(0.018)\end{array}$ & & \\
\hline Ext. Dep. $\times$ CAPFLOW & & & & & & & & & & & $\begin{array}{c}0.120 \\
(0.172)\end{array}$ & $\begin{array}{l}0.525 * * \\
(0.252)\end{array}$ \\
\hline Hausman-test (p-value) & & $3.02(0.08)$ & & $1.24(0.27)$ & & $2.22(0.14)$ & & $1.76(0.18)$ & & $0.30(0.58)$ & & $6.53(0.01)$ \\
\hline F-test (p-value) & & $321(0.00)$ & & $345(0.00)$ & & $211(0.00)$ & & $174(0.00)$ & & $70(0.00)$ & & $256(0.00)$ \\
\hline Sargan-test (p-value) & & $3.68(0.16)$ & & $2.76(0.10)$ & & $4.05(0.41)$ & & $1.37(0.71)$ & & $8.81(0.03)$ & & $9.73(0.02)$ \\
\hline No. of observations & 1223 & 1014 & 1154 & 1014 & 1223 & 1014 & 674 & 642 & 988 & 988 & 978 & 978 \\
\hline $\mathrm{R}^{2}$ & 0.44 & 0.44 & 0.50 & 0.44 & 0.44 & 0.44 & 0.60 & 0.58 & 0.52 & 0.52 & 0.43 & 0.43 \\
\hline
\end{tabular}

Note: $* * *$ indicates significance at the 1-percent level, $* *$ at the 5-percent level, $*$ at the 10-percent level. The dependent variable is the annual compounded growth rate in real output for the period 1980-90 for each ISIC industry in each country. See Table 2 for a description of the rest of the variables. Heteroskedasticity robust standard errors are in parentheses, except for the diagnostic tests where p-values are reported. 
Table A7: Growth in output, financial liberalization and integration. Split sample.

\begin{tabular}{|c|c|c|c|c|c|c|c|c|c|c|}
\hline \multirow{2}{*}{$\begin{array}{l}\text { Indicator of } \\
\text { Fin.lib. or } \\
\text { integration }\end{array}$} & \multirow{2}{*}{$\begin{array}{l}\text { Level of } \\
\text { Fin.dev. }\end{array}$} & \multirow[t]{2}{*}{ Model } & \multirow{2}{*}{$\begin{array}{l}\text { Industry } \\
\text { share }\end{array}$} & \multirow{2}{*}{$\begin{array}{l}\text { Ext.dep } \times \\
\text { Fin.dev. }\end{array}$} & \multirow{2}{*}{$\begin{array}{l}\text { Ext.dep } \times \\
\text { Fin.lib.or } \\
\text { integration }\end{array}$} & \multicolumn{3}{|c|}{ Diagnostic tests: } & \multirow[t]{2}{*}{$\mathrm{N}$} & \multirow[t]{2}{*}{$\mathrm{R}^{2}$} \\
\hline & & & & & & $\begin{array}{c}\text { Haus- } \\
\text { man }\end{array}$ & $\mathrm{F}$ & Sargan & & \\
\hline \multirow{6}{*}{ IMF80 } & \multirow{3}{*}{ High } & OLS & $\begin{array}{c}-0.364 * * \\
(0.150)\end{array}$ & $\begin{array}{c}0.161 \\
(0.100)\end{array}$ & $\begin{array}{c}0.031 * * \\
(0.015)\end{array}$ & & & & 419 & 0.51 \\
\hline & & & & & & & & & & \\
\hline & & IV & $\begin{array}{c}-0.368 * * * \\
(0.121)\end{array}$ & $\begin{array}{c}0.165^{*} \\
(0.098) \\
\end{array}$ & $\begin{array}{l}0.036^{*} \\
(0.021)\end{array}$ & $\begin{array}{c}0.21 \\
(0.65) \\
\end{array}$ & $\begin{array}{c}92 \\
(0.00) \\
\end{array}$ & $\begin{array}{c}7.30 \\
(0.03) \\
\end{array}$ & 419 & 0.51 \\
\hline & \multirow{3}{*}{ Low } & OLS & $\begin{array}{c}-0.796 * * * \\
(0.252)\end{array}$ & $\begin{array}{c}0.175 * * * \\
(0.064)\end{array}$ & $\begin{array}{l}-0.004 \\
(0.014)\end{array}$ & & & & 595 & 0.47 \\
\hline & & & & & & & & & & \\
\hline & & IV & $\begin{array}{c}-0.796 * * * \\
(0.202)\end{array}$ & $\begin{array}{c}0.175 * * * \\
(0.061)\end{array}$ & $\begin{array}{l}-0.007 \\
(0.015)\end{array}$ & $\begin{array}{c}0.12 \\
(0.73)\end{array}$ & $\begin{array}{c}486 \\
(0.00)\end{array}$ & $\begin{array}{c}4.82 \\
(0.09)\end{array}$ & 595 & 0.47 \\
\hline \multirow{5}{*}{ QCAP82 } & \multirow[b]{2}{*}{ High } & OLS & $\begin{array}{c}-0.350^{* *} \\
(0.149)\end{array}$ & $\begin{array}{c}0.099 \\
(0.199)\end{array}$ & $\begin{array}{c}0.021 \\
(0.033)\end{array}$ & & & & 419 & 0.50 \\
\hline & & IV & $\begin{array}{c}-0.410^{* * *} \\
(0.155)\end{array}$ & $\begin{array}{l}-0.159 \\
(0.163)\end{array}$ & $\begin{array}{l}0.164^{*} \\
(0.095)\end{array}$ & $\begin{array}{c}1.79 \\
(0.18)\end{array}$ & $\begin{array}{c}41 \\
(0.00)\end{array}$ & $\begin{array}{c}5.46 \\
(0.02)\end{array}$ & 419 & 0.48 \\
\hline & \multirow{3}{*}{ Low } & OLS & $\begin{array}{c}-0.794 * * * \\
(0.214)\end{array}$ & $\begin{array}{c}0.180 * * * \\
(0.066)\end{array}$ & $\begin{array}{l}-0.009 \\
(0.039)\end{array}$ & & & & 595 & 0.47 \\
\hline & & & & & & & & & & \\
\hline & & IV & $\begin{array}{c}-0.796 * * * \\
(0.205)\end{array}$ & $\begin{array}{c}0.177 * * * \\
(0.063)\end{array}$ & $\begin{array}{l}-0.003 \\
(0.043)\end{array}$ & $\begin{array}{c}0.04 \\
(0.84)\end{array}$ & $\begin{array}{c}595 \\
(0.00)\end{array}$ & $\begin{array}{c}1.29 \\
(0.26)\end{array}$ & 595 & 0.47 \\
\hline \multirow{4}{*}{ BHL80 } & \multirow[b]{2}{*}{ High } & OLS & $\begin{array}{c}-0.341^{* *} \\
(0.150)\end{array}$ & $\begin{array}{c}0.348 \\
(0.217)\end{array}$ & $\begin{array}{l}-0.036 \\
(0.028)\end{array}$ & & & & 419 & 0.50 \\
\hline & & IV & $\begin{array}{c}-0.341 * * \\
(0.1141)\end{array}$ & $\begin{array}{c}0.392^{*} \\
(0.019)\end{array}$ & $\begin{array}{l}-0.043 \\
(0.030)\end{array}$ & $\begin{array}{c}0.24 \\
(0.62)\end{array}$ & $\begin{array}{c}98 \\
(0.00)\end{array}$ & $\begin{array}{c}7.95 \\
(0.05)\end{array}$ & 419 & 0.50 \\
\hline & \multirow[b]{2}{*}{ Low } & OLS & $\begin{array}{c}-0.788 * * * \\
(0.215)\end{array}$ & $\begin{array}{c}0.188 * * * \\
(0.067)\end{array}$ & $\begin{array}{l}-0.013 \\
(0.019)\end{array}$ & & & & 595 & 0.47 \\
\hline & & IV & $\begin{array}{c}-0.801 * * * \\
(0.205)\end{array}$ & $\begin{array}{c}0.170 * * * \\
(0.065)\end{array}$ & $\begin{array}{c}0.007 \\
(0.024)\end{array}$ & $\begin{array}{c}1.94 \\
(0.16)\end{array}$ & $\begin{array}{c}194 \\
(0.00)\end{array}$ & $\begin{array}{c}2.87 \\
(0.41)\end{array}$ & 595 & 0.47 \\
\hline \multirow{4}{*}{$\begin{array}{l}\text { KS- } \\
\text { STOCK } 80\end{array}$} & \multirow{2}{*}{ High } & OLS & $\begin{array}{c}-0.400^{* *} \\
(0.160)\end{array}$ & $\begin{array}{c}0.183 \\
(0.141)\end{array}$ & $\begin{array}{c}-0.016 \\
(0.017)\end{array}$ & & & & 303 & 0.57 \\
\hline & & IV & $\begin{array}{c}-0.414 * * * \\
(0.152)\end{array}$ & $\begin{array}{l}-0.007 \\
(0.121)\end{array}$ & $\begin{array}{c}0.022 \\
(0.023) \\
\end{array}$ & $\begin{array}{c}2.17 \\
(0.14) \\
\end{array}$ & $\begin{array}{c}92 \\
(0.00) \\
\end{array}$ & $\begin{array}{c}1.86 \\
(0.60)\end{array}$ & 303 & 0.57 \\
\hline & \multirow{2}{*}{ Low } & OLS & $\begin{array}{c}-0.389 * * \\
(0.178)\end{array}$ & $\begin{array}{c}0.242 * * * \\
(0.077)\end{array}$ & $\begin{array}{c}0.008 \\
(0.015)\end{array}$ & & & & 339 & 0.65 \\
\hline & & IV & $\begin{array}{c}-0.390^{* *} \\
(0.166)\end{array}$ & $\begin{array}{c}0.239 * * * \\
(0.070)\end{array}$ & $\begin{array}{c}0.010 \\
(0.017)\end{array}$ & $\begin{array}{c}0.03 \\
(0.85)\end{array}$ & $\begin{array}{c}213 \\
(0.00)\end{array}$ & $\begin{array}{c}2.65 \\
(0.45)\end{array}$ & 339 & 0.65 \\
\hline
\end{tabular}

...table continues on next page. 
Table A7 (continued)

\begin{tabular}{|c|c|c|c|c|c|c|c|c|c|c|}
\hline \multirow{2}{*}{$\begin{array}{l}\text { Indicator of } \\
\text { Fin.lib. or } \\
\text { integration }\end{array}$} & \multirow{2}{*}{$\begin{array}{l}\text { Level of } \\
\text { Fin.dev. }\end{array}$} & \multirow[t]{2}{*}{ Model } & \multirow{2}{*}{$\begin{array}{l}\text { Industry } \\
\text { share }\end{array}$} & \multirow{2}{*}{$\begin{array}{l}\text { Ext.dep } \times \\
\text { Fin.dev. }\end{array}$} & \multirow{2}{*}{$\begin{array}{c}\text { Ext.dep } \times \\
\text { Fin.lib.or } \\
\text { integration }\end{array}$} & \multicolumn{3}{|c|}{ Diagnostic tests: } & \multirow[t]{2}{*}{$\mathrm{N}$} & \multirow[t]{2}{*}{$\mathrm{R}^{2}$} \\
\hline & & & & & & $\begin{array}{c}\text { Haus- } \\
\text { man }\end{array}$ & F & Sargan & & \\
\hline \multirow{4}{*}{$\begin{array}{l}\text { CAP- } \\
\text { STOCK }\end{array}$} & \multirow[b]{2}{*}{ High } & OLS & $\begin{array}{c}-0.340 * * \\
(0.151)\end{array}$ & $\begin{array}{c}0.168 \\
(0.113)\end{array}$ & $\begin{array}{c}-0.008 \\
(0.009)\end{array}$ & & & & 419 & 0.50 \\
\hline & & IV & $\begin{array}{c}-0.341 * * \\
(0.142) \\
\end{array}$ & $\begin{array}{c}0.140 \\
(0.102) \\
\end{array}$ & $\begin{array}{c}-0.001 \\
(0.008) \\
\end{array}$ & $\begin{array}{c}2.32 \\
(0.13) \\
\end{array}$ & $\begin{array}{c}245 \\
(0.00) \\
\end{array}$ & $\begin{array}{c}8.98 \\
(0.03) \\
\end{array}$ & 419 & 0.50 \\
\hline & \multirow[b]{2}{*}{ Low } & OLS & $\begin{array}{c}-0.539 * * * \\
(0.139)\end{array}$ & $\begin{array}{c}0.153 * * \\
(0.064)\end{array}$ & $\begin{array}{l}-0.007 \\
(0.014)\end{array}$ & & & & 569 & 0.58 \\
\hline & & IV & $\begin{array}{c}-0.542 * * * \\
(0.133)\end{array}$ & $\begin{array}{c}0.161 * * * \\
(0.060)\end{array}$ & $\begin{array}{c}0.004 \\
(0.020) \\
\end{array}$ & $\begin{array}{c}0.68 \\
(0.41) \\
\end{array}$ & $\begin{array}{c}74 \\
(0.00) \\
\end{array}$ & $\begin{array}{c}1.43 \\
(0.70) \\
\end{array}$ & 569 & 0.58 \\
\hline \multirow{4}{*}{$\begin{array}{l}\text { CAP- } \\
\text { FLOW }\end{array}$} & \multirow[b]{2}{*}{ High } & OLS & $\begin{array}{c}-0.356^{* *} \\
(0.150)\end{array}$ & $\begin{array}{c}0.090 \\
(0.103)\end{array}$ & $\begin{array}{c}0.197 \\
(0.167)\end{array}$ & & & & 419 & 0.50 \\
\hline & & IV & $\begin{array}{c}-0.365 * * * \\
(0.139)\end{array}$ & $\begin{array}{c}0.060 \\
(0.100)\end{array}$ & $\begin{array}{l}0.319^{*} \\
(0.187)\end{array}$ & $\begin{array}{c}2.68 \\
(0.10)\end{array}$ & $\begin{array}{c}594 \\
(0.00)\end{array}$ & $\begin{array}{c}1.86 \\
(0.60)\end{array}$ & 303 & 0.57 \\
\hline & \multirow[b]{2}{*}{ Low } & OLS & $\begin{array}{c}-0.804 * * * \\
(0.222)\end{array}$ & $\begin{array}{c}0.174 * * \\
(0.064)\end{array}$ & $\begin{array}{l}-0.110 \\
(0.395)\end{array}$ & & & & 559 & 0.46 \\
\hline & & IV & $\begin{array}{c}-0.809 * * * \\
(0.211)\end{array}$ & $\begin{array}{c}0.169 * * * \\
(0.061)\end{array}$ & $\begin{array}{c}0.364 \\
(0.565)\end{array}$ & $\begin{array}{c}1.31 \\
(0.25)\end{array}$ & $\begin{array}{c}82 \\
(0.00)\end{array}$ & $\begin{array}{c}3.93 \\
(0.27)\end{array}$ & 559 & 0.58 \\
\hline
\end{tabular}

Note: $* * *$ indicates significance at the 1-percent level, ** at the 5-percent level, $*$ at the 10-percent level. The dependent variable is the annual compounded growth rate in real output for the period 1980-90 for each ISIC industry in each country. See Tables 2 and 3 for a description of the other variables. "High" ("Low") financial development refers to countries with above (below) median accounting standards. Heteroskedasticity robust standard errors are in parentheses, except for the diagnostic tests where p-values are reported. 